Article

\title{
Sustainable Business Models: A Bibliometric Performance Analysis
}

\author{
Magdalena Marczewska ${ }^{1, *(\mathbb{D})}$ and Mariusz Kostrzewski ${ }^{2}$ (D) \\ 1 Faculty of Management, University of Warsaw, 1/3 Szturmowa Street, 02-678 Warsaw, Poland \\ 2 Faculty of Transport, Warsaw University of Technology, 75 Koszykowa Street, 00-662 Warsaw, Poland; \\ mariusz.kostrzewski@pw.edu.pl \\ * Correspondence: mmarczewska@wz.uw.edu.pl; Tel.: +48-22-553-4002
}

Received: 28 September 2020; Accepted: 17 November 2020; Published: 19 November 2020

\begin{abstract}
Sustainable business models have become a phenomenon of global interest. Since the beginning of the 21st century, companies have sought to shift from traditional business models towards sustainable ones in order to leverage their sustainable performance and increase their competitive advantage. The aim of this paper is to provide an extensive overview of the academic research on sustainable business models with the focus on inquiry of main trends related to business and economics studies and identification of future research directions. This paper reviews existing literature on sustainable business models in order to map this research stream and identify the most substantial contributors to the advances of research in this field. It contributes to the existing body of knowledge on sustainable business models by: (1) describing the most influential and high-impact researchers/authors, journals, and papers; (2) highlighting main and most important research trends related to sustainable business models in studies on business and economics; and (3) identifying future research agendas in investigating sustainable business models from business and economics perspectives.
\end{abstract}

Keywords: sustainable business model; sustainable development; business model; sustainability; bibliometric analysis; mapping science; business models for sustainability; COVID-19

\section{Introduction}

Sustainable business models have received substantial recognition from practitioners and academics in the past two decades. An increasing number of companies adopted sustainable business models in order to leverage their sustainable performance and increase their competitive advantage [1]. The number of scientific publications on the topic has also noticeably increased, which has changed since the time when the broader literature discourse on business model innovation had almost entirely ignored issues of sustainability [2,3]. Therefore, literature reviews seem to be useful in order to describe and map the current research stream.

The beginning of this century was the point in time when sustainable business models were recognized as worth analyzing. Kim M. [4], Saeed K.A., Hwang Y. and Grover V. [5] were among the first researchers who investigated this research area (the mentioned authors published their papers in 2002 and 2004, however, it should be taken into consideration that their contributions were developed in previous years). During the past two decades, various contributions related to sustainable business models have been published. The two-decade period of time can be treated as a certain milestone in particular investigations, therefore, the authors of this paper decided to review the actual literature on sustainable business models towards mapping the research stream and identify the most substantial contributors and contributions in this area of interest. 
The precisely described evolution of the term "business models" and its conceptualization into "sustainable business models" is presented in [6], where the authors also summarized three definition types of business models: as "a model of an organizational system, ( . . ) as an abstract characteristic of an organizational unit, $(\ldots)$ or with a reduced scope that equates the term with individual elements of other authors' definitions or reduce it to achieve certain means" [6]. Moreover, according to [7], it is possible to combine certain concepts and methods in order to transform business models of companies into sustainable business models. However, in [8], the authors mentioned that business models' decisions measuring parameters are not intended for the formulation of a coherent sustainable business model. Therefore, it can be concluded that business models and sustainable ones should be treated separately. Several publications provided a collection of definitions of sustainable business model's concept. Among them, [6,9-12] can be mentioned. The authors of numerous publications provided differentiated conceptual definitions of this term, as well as sustainable business models' application propositions [10]. Admittedly, the current paper focuses on sustainable business models and aims to capture a wide overview of this research stream. Thus, it does not provide a unified and universal definition of sustainable business models, but rather presents an overview of selected definitions, which constitute a basis for this analysis. The selected definitions are presented in Table 1. The definitions were set in an inverse-synchronous manner. One should bear in mind that sustainability business models are also described under other names and labels, for example business models for sustainability [13]; nevertheless, the authors of current paper use the term "sustainability business models", unless otherwise specified.

Table 1. Selected definitions of sustainable business models.

\begin{tabular}{ccc} 
Definition & Year of Publication & Source \\
\hline $\begin{array}{c}\text { A sustainable business model supports creation of sustainable value for } \\
\text { customers and all other stakeholders, create[s] and deliver[s] this value, } \\
\text { and "capture economic value while maintaining or regenerating natural, } \\
\text { social, and economic capital beyond its organizational boundaries [12] } \\
\text { (p. 6)". }\end{array}$ & 2020 [14] (p. 3) \\
\hline $\begin{array}{c}\text { The sustainable business models' concept is ( .. ) strongly related to } \\
\text { the circular economy concept through the approach of the planet }\end{array}$ & 2018 & [15] (p. 328) \\
perspective, by minimizing waste, recycling, and reintegration, and \\
producing renewable energy and clean products and services.
\end{tabular}


Table 1. Cont.

\begin{tabular}{|c|c|c|}
\hline Definition & Year of Publication & Source \\
\hline $\begin{array}{l}\text { Sustainable business models are defined by indicating five perspectives } \\
\text { (P1-P5) for innovation development: P1. sustainable value incorporates } \\
\text { economic, social and environmental benefits conceptualized as value } \\
\text { forms; P2. Sustainable business models [added by the authors] require a } \\
\text { system of sustainable value flows among multiple stakeholders } \\
\text { including the natural environment and society as primary stakeholders; } \\
\text { P3. Sustainable business models [added by the authors] require a value } \\
\text { network with a new purpose, design and governance; P4. Sustainable } \\
\text { business models [added by the authors] require a systemic } \\
\text { consideration of stakeholder interests and responsibilities for mutual } \\
\text { value creation; P5. Internalizing externalities through product-service } \\
\text { systems [added by the authors] enables innovation towards sustainable } \\
\text { business models [added by the authors]. }\end{array}$ & 2017 & [18] (p. 605) \\
\hline $\begin{array}{l}\text { ( ... ) business models for sustainability }(\ldots) \text { are deemed to consist of } \\
\text { pillars and building blocks, whereby building blocks are defined such } \\
\text { that they correspond to the central aspects of sustainable development. }\end{array}$ & 2017 & [19] (p. 145) \\
\hline
\end{tabular}

A business model for sustainability helps in describing, analyzing,
managing, and communicating (i) a company's sustainable value
proposition to its customers, and all other stakeholders; (ii) how it
creates and delivers this value; (iii) and how it captures economic value
while maintaining or regenerating natural, social, and economic capital
beyond its organizational boundaries (this definition is an indirect one,
however, "business model for sustainability" is treated here as
"sustainable business model", especially in that sustainable business
model or business model for sustainability are equal terms [20]).

A business model for sustainability helps describing, analyzing, managing, and communicating (i) a company's sustainable value proposition to its customers and all other stakeholders; (ii) how it creates and delivers this value; (iii) and how it captures economic value while maintaining or regenerating natural, social and economic capital beyond its organizational boundaries.

Sustainable business models [added by the authors] are a simplified representation of the elements, the interrelation between these elements, and the interactions with its stakeholders that an organisational unit uses to create, deliver, capture, and exchange sustainable value for, and in collaboration with, a broad range of stakeholders, where two key elements of sustainable business model innovation can be considered stakeholders.

Models defined by their measures: In case of [added by the authors] ( ... ) an enterprise determines the appropriate inputs, resource flows, and value decisions and its role in ecosystems, whether natural, social, or economic. Whereas [added by the authors] sustainability measures are those indicators that assess the outputs and effects of business model decisions.

Sustainable business models [added by the authors] incorporate sustainability as an integral part of the company's value proposition and value creation logic. As such, business models for sustainability [added by the authors] provide value to the customer and to the natural environment and/or society.

Sustainable business models ( . . ) incorporate a triple bottom line approach and consider a wide range of stakeholder interests, including environment and society. They are important in driving and implementing corporate innovation for sustainability, can help embed sustainability into business purpose and processes, and serve as a key 
Table 1. Cont.

\begin{tabular}{|c|c|c|}
\hline Definition & Year of Publication & Source \\
\hline $\begin{array}{l}\text { (... ) the four elements of a business model-value proposition, supply } \\
\text { chain, customer interface, and financial model ( ... ) provide a basic set } \\
\text { of normative principles for sustainable business models, which need to } \\
\text { be fulfilled in order to contribute to a successful marketing of } \\
\text { sustainable innovations. }\end{array}$ & 2013 & [9] (p. 13) \\
\hline $\begin{array}{l}\text { Regarding [4], a sustainable business model can be understood in terms } \\
\text { of specific characteristics of each of the following elements: the analysis } \\
\text { of business models involves assessing the way in which a firm } \\
\text { combines a value proposition with supply chain management, the } \\
\text { interface with customers, and a revenue model. }\end{array}$ & 2013 & [24] (p. 5) \\
\hline $\begin{array}{l}\text { Sustainable business models seek to go beyond delivering economic } \\
\text { value and include a consideration of other forms of value for a broader } \\
\text { range of stakeholders. ( ...) Sustainable business models as a } \\
\text { prerequisite must be economically sustainable. }\end{array}$ & 2013 & [25] (p. 484) \\
\hline $\begin{array}{l}\text { The future sustainable [added by the authors] business models should } \\
\text { have a global market perspective, taking into account the development } \\
\text { of new industrialized countries as well as the need for more sustainable } \\
\text { products and services. }\end{array}$ & 2012 & [26] (p. 88) \\
\hline $\begin{array}{l}\text { Sustainable business models create customer and social value by } \\
\text { integrating social, environmental, and business activities, after [6] }\end{array}$ & 2012 & [27] (p. 112) \\
\hline $\begin{array}{l}\text { A business model that creates competitive advantage through superior } \\
\text { customer value and contributes to a sustainable development of the } \\
\text { company and society can be interpreted as a sustainable business model } \\
\text { and an organizational eco-innovation. }\end{array}$ & 2010 & [28] (p. 23) \\
\hline $\begin{array}{l}\text { Sustainable business model reflects cultural, structural, firm-level, and } \\
\text { systems-level attributes arising from the case study data (this definition } \\
\text { takes into consideration a wide range of stakeholders and considers the } \\
\text { environment and society as stakeholders according to [23]; in [23] } \\
\text { environment and society are underlined as key stakeholders). }\end{array}$ & 2008 & [29] (p. 104) \\
\hline
\end{tabular}

Source: own elaboration based on [6,9-12] and other references directly mentioned in the table.

This paper is organized as follows. The forthcoming two subsections describe literature review (as a background of the paper) and present a clear research aim of this study. The next section is focused on research methods and data used with the view to clarify the research procedure. Subsequently, the results of further deeply investigated study are presented, including performance-based bibliometric analysis, citation analysis, productivity, and influence of researchers. Finally, the last section discusses the main conclusions of this study and presents research limitations.

\subsection{Background}

Kim M. [4], Saeed K.A., Hwang Y. and Grover V. [5] were the first researchers that highlighted the importance of sustainable business models. Over the last two decades, other studies related to sustainable business models have been published as well. The authors of these studies considered various aspects of sustainable business models, e.g., their classification or categorization $[9,23,30]$ or industry specific analyses [31-33]. Whereas publications $[9,23,30]$ were more complex studies and these are commented below as such; the industry-specific publications revealed interesting aspects of sustainable business models as well. In [31], the author presented an opinion on why the automotive industry's business models are not sustainable and discussed them in selected aspects of sustainability, namely environmental, social, and economic one. Moreover, the author discussed the potential of a sustainable automotive industry and its business models as well. The topic of alternative business models for automotive industry was continued in [34] (both mentioned publications' authors cooperate with each other, as it can be observed in references given in [34]). In [32], the authors analyzed bibliometric aspects for a more specific part of the automotive industry, i.e., electric cars industry, which resulted in an opinion that this sector focuses on business model decisions for charging technologies, 
driver services, electricity management, commercial contracts, and plant. The authors of [33] primarily presented a sustainable business model for reverse logistics operations with a narrative review as the introduction to their research.

There are also several direct systematic review articles that tackle the concept of sustainable business models from diverse perspectives. The authors of [30] found that business models categorization includes electronic business models, business model innovations and sustainable business models-the last one is the current paper's main area of interest. The authors of [9] studied sustainable innovation by adopting a business model perspective. The authors of [23] elaborated an important and fundamental review on sustainable business models, categorizing their archetypes. The authors collected various mechanisms and solutions, which contributed in the conversion of business models into sustainable ones. Their paper is highly appreciated in the scientific community, presumed only by the number of its citations. However, since the review analysis of this group of authors, i.e., the last 6 years, numerous new conceptual and empirical publications have been released. A few years later, the authors of [18] developed a unified theoretical perspective for understanding business model innovations that led to better organizational economic, environmental and social performances. Since this was a highly theoretical contribution, it can be treated as a review study. This is a valuable review study on business model innovation and the concept of sustainable business models, as [6] focused on understanding why and how the organizations adopted these frameworks. The authors considered aspects, activities and challenges that occurred during the creation and development of new, sustainable business models and tried to formulate some managerial implications. In addition, the paper presented an elaboration on sustainable business model concepts and definitions. In another paper [35], the authors dived deeper into sustainable business models based on literature review and case studies analysis and proposed a framework for circular business models. The same year, the other authors published a review [36] describing how sustainable business models affected companies' competitiveness. A year later, in [37], sustainable business models focusing on taxonomy of their application categories and accurate alignment of conceptual and empirical papers to the predefined categories were presented. Moreover, the review paper [10] focused on sustainable business models and their operational practices and provided insights into opportunities for business practitioners to integrate their traditional business models with sustainability. An interesting analysis of the current body of knowledge on business model research domain can be found in [30], in which the authors, based on text mining methods, identified that sustainable business models constitute one of three main research areas and are treated as a contemporarily significant topic. In fact, a shift towards sustainable and inclusive business models is of high importance from a social point of view and is crucial to reach Sustainable Development Goals (SDG) (2030 Agenda) adopted by United Nations member states in 2015 [38]. Reaching goals given in SDG led the authors of [39] to the literature review report and discussion of whether intellectual capital, through the implementation of knowledge management processes, can influence entrepreneurial orientation towards design and implementation of sustainable business models in organizations.

While the literature on sustainable business models is wide, there are not many review articles presenting a holistic approach to this research subject enriched by quantitative analyses. Indeed, many of these publications made some great contributions to the body of knowledge thanks to descriptive statistical techniques $[6,10,23,37]$, however, almost completely disregarding other available techniques and indicators that are used in bibliometrics analysis, such as indicators of and in-depth citation analysis. The available reviews are mainly content-based papers focused on systematic literature review with a very limited use of bibliometric methods and techniques. This paper tries to fill this gap and enriches bibliometric studies by applying equations such as: a ratio of influence and a coefficient of a number of citations per year, adapted by the authors into a weighted coefficient of a number of citations per year in the case of particular publication(s). 


\subsection{The Aims of the Paper and Research Questions}

Based on the background analyses presented above, the authors defined the following objectives of this paper.

The aim of this paper is to provide an extensive overview of the academic research on sustainable business models with the focus on inquiry of main trends within this research in studies related to business and economics and identification of future research directions. This paper reviews the existing literature on sustainable business models in order to map this research stream from managerial perspective and identify the most substantial contributors to the advances of the research in this field. It contributes to the existing body of knowledge on sustainable business models by: (1) describing the most influential and high-impact researchers/authors, journals, and papers; (2) highlighting the main and most important research trends related to sustainable business models in studies on business and economics; and (3) identifying future research agendas in investigating sustainable business models from business and economics perspectives. In contrast, other review papers in the field concentrate on identification, interpretation and summaries of important elements within sustainable business models framework or conceptual issues.

With this in mind, in order to investigate the research base on sustainable business models in business and economics studies, in line with the research objective presented in the previous paragraph of this paper, the following set of three main research questions (RQ) was formulated:

- RQ1: What sources, scholars, and papers have been most influential in research on sustainable business models overtime in studies related to business and economics?

- RQ2: What are the main and most important research trends related to sustainable business models in business and economics studies?

- RQ3: What are the future research directions in investigating sustainable business models from business and economics perspectives?

Additionally, the paper presents a complex overview of the research base on sustainable business models and discusses how the dynamic of scientific research on sustainable business models developed overtime in studies related to business and economics, compared to other areas.

\section{Materials and Methods}

Literature review is characterized by certain typology. In [40], Grant and Booth summarized this typology, distinguishing certain approaches grouped into two categories. The first category consists of approaches (methods) with formal assessment and analyses, while the second category is characterized by less formal approaches (methods). Among the methods of literature review, which do not include a formal assessment or analysis, the following can be mentioned [40]:

- a narrative review that is typically a research background in a field of particular paper, thesis or dissertation (narrative review results in synthesis of selected research and it is given most often in a descriptive manner rather than statistical one [41]),

- a critical review that compares and evaluate a number of perspectives of a particular research problem,

- a scoping review that highlighting gaps in the literature and is intended to clarify a need for a research,

- a conceptual review that presents an overview according to concepts, categories, or themes,

- and a state-of-the-art review that focuses on research published recently in a particular field of interest.

Formal assessments and analyses are employed in more rigorous literature review methods [40]. A systematic literature review (systematic review), which meets specific criteria, and quantitative or qualitative meta-analysis review, are mentioned among them. A systematic review is a content-based 
review. A typical systematic review starts with a research question and consists of identification, selection and synthesis of high-quality research evidence and publications connected to a particular field of interest. Systematic reviews are commonly applied to test a single hypothesis defined based on a research question or a series of related hypotheses [41]. A meta-analysis review is understood as a review that is based on particular statistics applied in order to develop a synthesis for results presented in several studies [41]. A quantitative (objective type of this method) or qualitative (subjective type of this method) meta-analysis review can actually become a part of a systematic review; nevertheless, meta-analysis review is given as a separate method in the literature [41].

As it was mentioned in [41], a systematic review's aim is "to provide an objective, comprehensive summary of the best evidence", however, the current article's aim was not to present such a comprehensive summary. Literature is overloaded with research on sustainable models, sustainable business models, business models, etc., therefore, the authors would like to present what are the patterns in actions of researchers (in order to present effectiveness of researchers' activities) and also to verify if the current knowledge on the subject matter is balanced. It was assumed that it would be balanced if there was a diversity of authors, quotations, sources of publications, however, there are certain biases, which are described within this article (potential biases may be a consequence of pet theories, funders satisfying, appetence of positive results obtainment in order to be published and quoted, etc.). Objectivity of such reviews may be disputable, since a pair of similar systematic reviews can be summarized with entirely opposite conclusions, as it was mentioned in [41]. A quantitative approach can be called into question less, since values are more objective than descriptions. Consequently, in contrast to the classic types of literature review methods, the authors of this article proposed bibliometric performance analysis (enriched by certain research questions) coupled with graphical mapping technique in order to cope with the issue of sustainable business models analysis. Such an approach allowed to exclude consideration of authorial bias since it presents impact in the considered research area, not content-based evaluations. Such a method and technique coupling can be treated as enriched quantitative meta-analysis review in comparison to classically understood meta-analyses.

The paper uses an exhaustive bibliometric analysis, involving a bibliometric performance analysis and a graphic mapping of the references in the sustainable business models research field. It classifies selected types of publications that are framed in the sustainable business models field through the analysis of bibliographic records obtained from the Scopus database and performs graphical mapping of bibliometric material with the use of VOSviewer software (version 1.6.15, Nees Jan van Eck and Ludo Waltman, Melbourne, Leiden, The Netherlands).

According to [42], the Web of Science (WoS) database has been the main bibliometric source of scientific evaluation. Nevertheless, recently, the Scopus database has become a good alternative to the WoS since the Scopus performs nowadays the same tasks as the WoS in the aspects of literature searching and citation analyses of bibliometric records.

The Scopus database's content introduction [43] showed that this database contains over 70 million records (with cited 1.4 billion references). These records have been acquired from more than 39,700 serial titles, e.g., scientific journals (with more than 25,100 currently active titles), and more than 221,000 books. Moreover, almost 8 million conference papers collected during c.a. 100,000 conference events are included in the Scopus database [44]. Such a collection was acquired from more than 5000 international publishers. The authors of [42] claimed after [45] that the Scopus indexes most of the journals, which are also indexed in the WoS database, and a greater number of exclusive journals compared to the WoS. In fact, more than 21,100 journals are collected in the WoS database, which constitutes slightly lower quantity than in the Scopus [46]. Additionally, c.a. 104,500 books are almost half of the titles collected in the Scopus. On the other hand, 205,000 conference proceedings are collected in the WoS database, which is conversely more than in the case of the Scopus database [46]).

The analysis was conducted following the five-stage research procedure presented in Figure 1.

The first stage of research procedure was based on identification of keywords relevant to the research objective. This was performed as a result of the literature review carried out before the 
research was finally conceptualized and resulted in choosing one keyword, namely "sustainable business model". Then, multiple test searches of various phrases were conducted in the widest search fields of Scopus and WoS databases (i.e., "Article title, Abstract, Keywords") in order to identify the most appropriate one for the final search. As a result, the following phrase was chosen: "sustainable business model *" OR "business model AND sustainab" OR "business model* for sustainability". The third stage of the research procedure aimed to confirm the validity and relevance of the investigations, by applying the final search phrase in both databases. It occurred that the majority of the articles, which are indexed in the WoS database, are indexed in the Scopus databases as well, however, the latter one indexes a greater number of exclusive journals compared to the WoS. Moreover, the total number of records in the WoS database (541) was lower than in the Scopus (776).

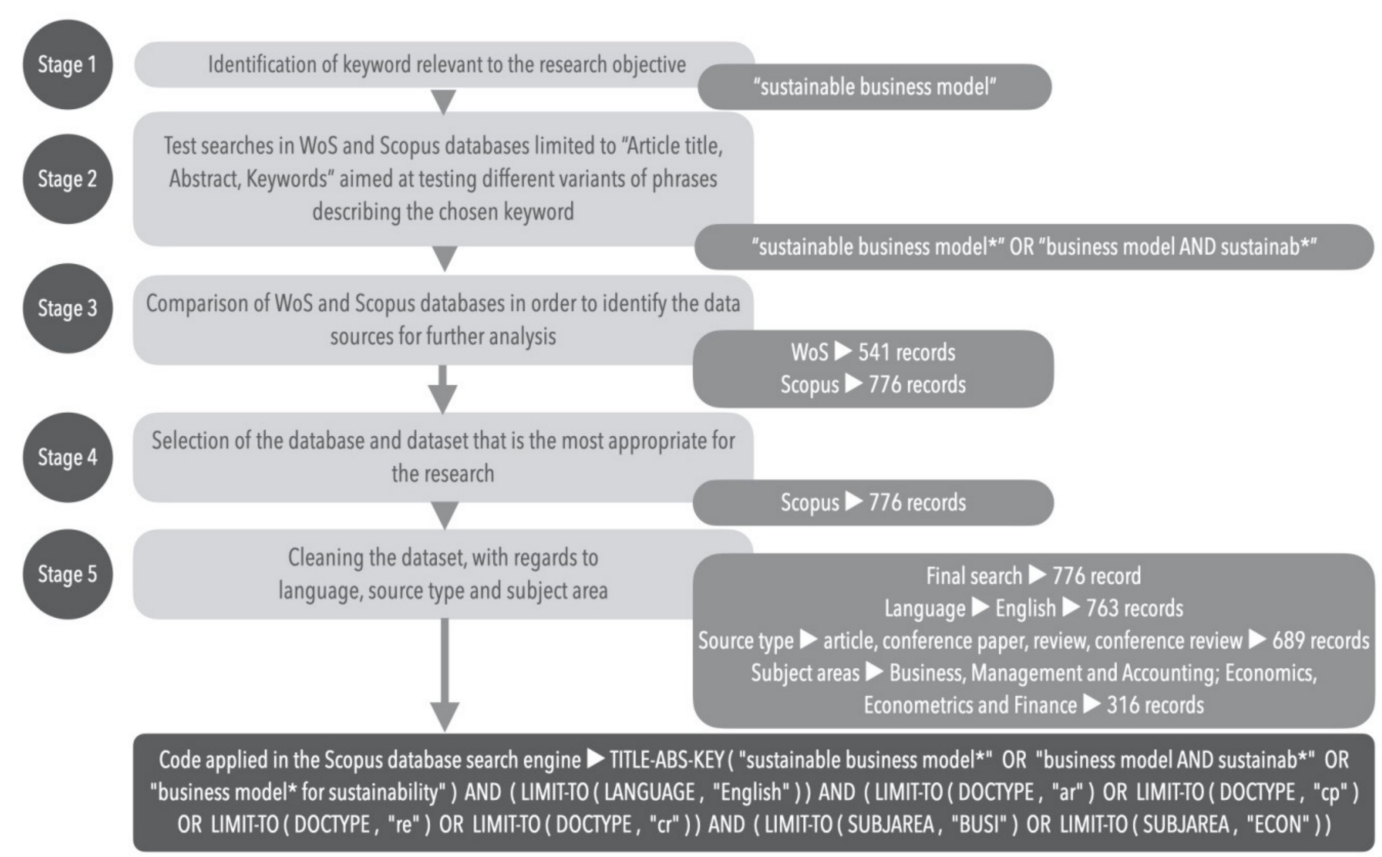

Figure 1. Stages of the research procedure. Source: own elaboration.

Taking all above into account, in the fourth stage of the research procedure, the Scopus database was chosen to be the main source of bibliometric records for this study. Finally, cleaning of the obtained dataset was performed, with regards to the following criteria: language, source type, subject area. The finals search in the Scopus database resulted in return of 776 records in total. Considering the language of the publications after making a decision to analyze the publications in English, only 763 references were returned. Most of them (689 references) were classified as articles, conference papers, reviews, and conference reviews, thus these types of references were of the authors' interest. After screening titles, abstracts and keywords of obtained search results, it turned out that most papers related to business and economics studies fall into the following Scopus subject areas: Business, Management and Accounting and Economics, Econometrics and Finance. For this reason, the studies to be evaluated were selected from these areas and constituted a final research sample of 316 records.

The search process was limited to research published between 2002 and 2020 (first quarter-the final search was performed on 21 April 2020). In 2002, the first paper on sustainable business models was published. 


\section{Research and Results}

\subsection{General Bibliometric Analysis}

The research on sustainable business models started in 2002 and has been constantly gaining popularity in the last two decades. The following section of this paper presents the main results of the bibliometric analysis of this research area. The search process was conducted in April 2020 and resulted in 776 records on the topic available in the Scopus database. Figure 2 presents the dynamics of scientific research on sustainable business models developed overtime. The first scientific article was published in 2002. Until 2006, there were less than 10 publications on sustainable business models per year, and in 2013 the number of papers exceeded 50 items. The vast majority of all contributions to the topic were published last decade. The growth in number of records is exponential.

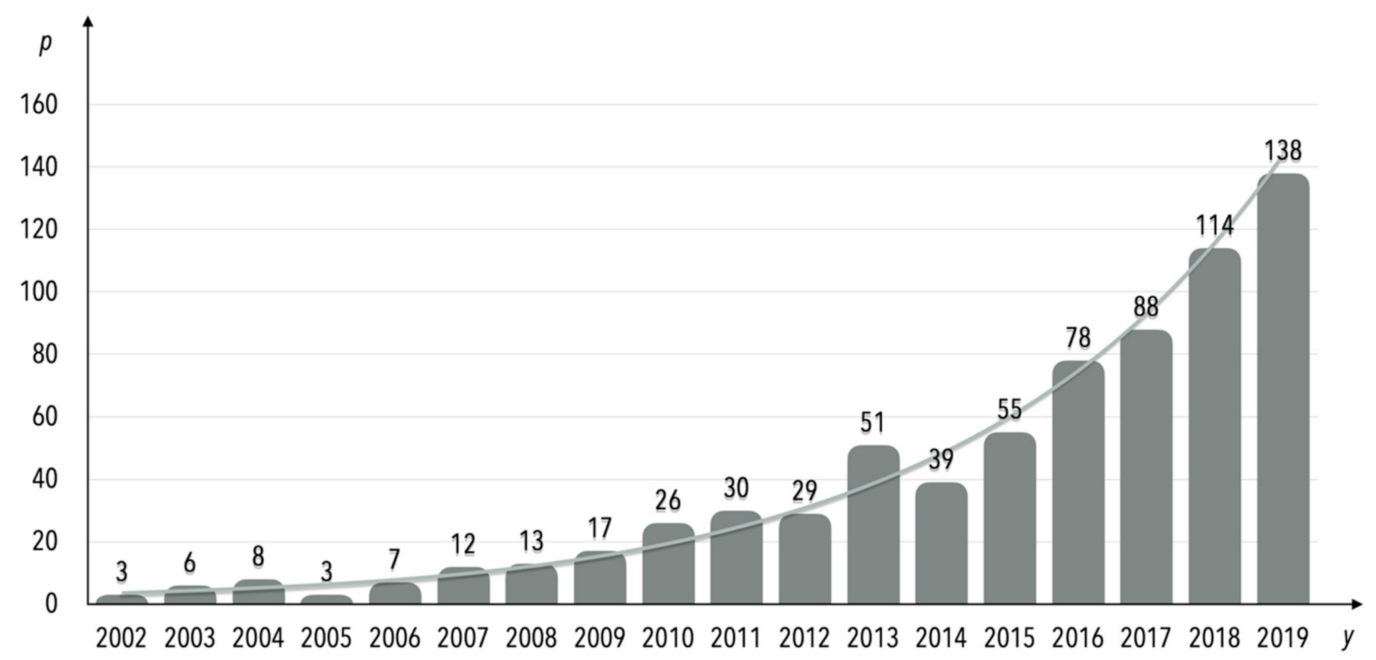

Figure 2. Evolution of publications on sustainable business models literature, 2002-2020 $(n=776)$. Source: own elaboration based on Scopus database.

Figure 3 presents details on records obtained from the Scopus database presented in line with the criteria listed in the research procedure (see Figure 1). The left bars per a particular year indicate the total number of publications per year in the Scopus database for sustainable business models research; the centered bars indicate the number of articles, conference papers, reviews and conference reviews published in English; whereas the right bars indicate the number of articles, conference papers, reviews and conference reviews in English in the Scopus database for sustainable business models research in particular indexed in Business, Management and Accounting and Economics, Econometrics and Finance subject areas. It can be observed that sustainable business models research dynamics in business and economics studies developed in line with the general publishing trend in other scientific disciplines. This means that researchers' interest in this concept is steadily developing within the different scientific communities representing different research fields. 


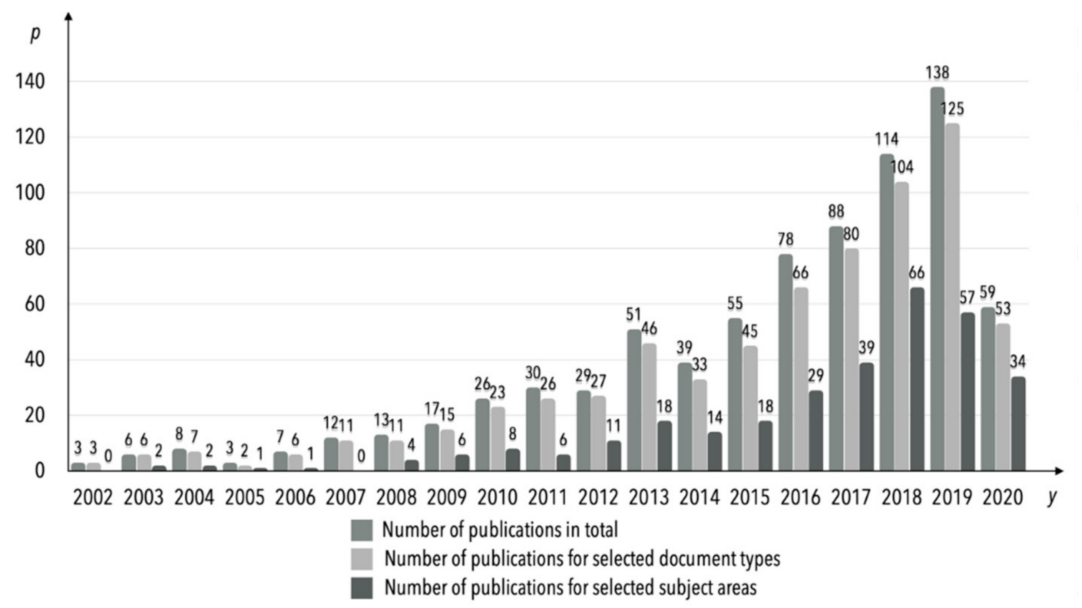

Figure 3. Number of publications $(p)$ per year $(y)$ in sustainable business models research between 2002 and 2020 in total, for selected document types, for selected subject areas. Source: own elaboration based on data from Scopus database.

Interestingly, almost $94 \%$ of publications from the defined dataset are indexed as contributions related to Business, Management and Accounting, and account for almost $41 \%$ of all publications on sustainable business models listed in the Scopus database. This subject area is, at the same time, the most important subject area within all 25 areas related to the analyzed topic, followed by Environmental Science and Engineering (with around 30\% of classified contributions, respectively).

It should also be noted that many of the publications listed under Business, Management and Accounting and Economics, Econometrics and Finance subject areas are also indexed in other subject areas (Figure 4). Among subject areas listed in the Figure 4, Environmental Science, Engineering and Energy can be considered as leading, with several dozen percent shares of classified publications; Economics, Econometrics and Finance along with Social Sciences can be seen as significant, with several percent share of publications, Decision Sciences, Computer Science and Agricultural and Biological Sciences as less important with a few percent share, and other as marginal, with less than $2 \%$ share.

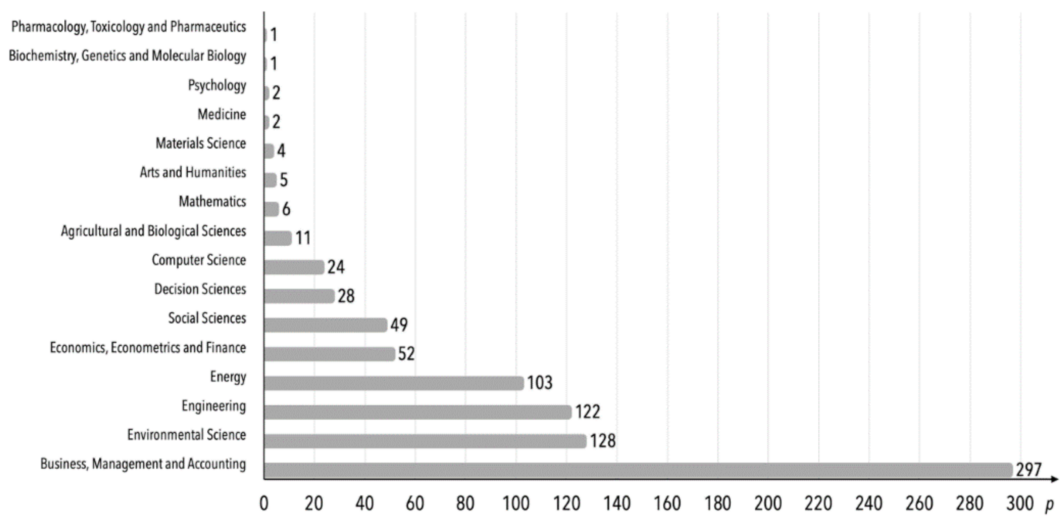

Figure 4. Number of articles, conference papers, reviews and conference reviews $(p)$ in Scopus in sustainable business models research indexed in Business, Management and Accounting and Economics, Econometrics and Finance areas indexed at the same time in other subject areas (total 316). Source: own elaboration based on Scopus database.

With the view of the aim of this study presented in the introductory part, this paper analyzes a sample of 316 papers classified in two Scopus subject areas: Business, Management and Accounting and Economics, Econometrics and Finance; $85.13 \%$ of this sample are articles (269 publications), $8.86 \%$ are conference papers ( 28 publications), $5.38 \%$ are review papers (17 publications), and $0.63 \%$ are 
conference reviews (2 publications). Interestingly, nearly one third of analyzed papers were published in Journal of Cleaner Production. Top journals publishing papers in sustainable business models research indexed in Business, Management and Accounting and Economics, Econometrics and Finance subject areas according to the number of published records are presented in Table 2.

Table 2. Top journals publishing papers in sustainable business models research indexed in Business, Management and Accounting and Economics, Econometrics and Finance subject areas by number of publications.

\begin{tabular}{cc} 
Source & Number of Publications \\
\hline Journal of Cleaner Production & 96 \\
Business Strategy and the Environment & 9 \\
Organization and Environment & 9 \\
British Food Journal & 7 \\
Lecture Notes in Business Information Processing & 5 \\
Corporate Governance Bingley & 3 \\
Corporate Social Responsibility and Environmental Management & 3 \\
International Journal of Business Excellence & 3 \\
Management Decision & 3 \\
Resources Conservation and Recycling & 3 \\
Sustainability Accounting Management and Policy Journal & 3 \\
\hline
\end{tabular}

Source: Own elaboration based on data from the Scopus database.

The increase in number of publications on sustainable business models over the years can be explained by several factors. Firstly, the topic is gaining attention from managerial perspective, thus the number of researchers aim to capture its characteristics (detailed analysis of authors contributing to the global discussion on sustainable business models is presented below). Secondly, taking into account the importance of this topic, journals seek to receive contributions describing this phenomenon. The flagship example of such a journal is Journal of Cleaner Production. Its relatively high impact factor attracts researchers, and the profile of the journal focused on sustainability research and practice seems to be a perfect match for this research area. Almost all subject areas of the journal focus on various aspects of sustainability and support it: Sustainable development and sustainability, sustainable consumption, environmental and sustainability assessment, sustainable products and services, corporate sustainability and corporate social responsibility, education for sustainable development, governance, legislation, and policy for sustainability. Even in its leading subject area, which is cleaner production and technical processes, the connection to sustainability is hidden under subcategories such as green/sustainable chemistry, green/sustainable building construction, green/sustainable engineering.

The research interests of authors publishing papers on sustainable business models in Journal of Cleaner Production can be classified into two general topics, based on the analysis of clusters of keywords: (1) circular economy and business models (circular economy, business model for sustainability, sustainable business model, sustainable business models, corporate sustainability, sustainable innovation, business model innovation, product-service systems); (2) entrepreneurship and sustainability (keywords: business model, business models, value proposition, value creation, sustainability, sharing economy). Papers published in Business Strategy and the Environment, as well as in Organization and Environment, concentrate more on the organizational perspective and investigate sustainable business models with the focus on sustainable value creation and sustainable development. British Food Journal publishes contributions related to sustainability in food industry, where sustainable business models are treated as supplementary to the main topic, whereas publications in Lecture Notes in Business Information Processing does not seem to be thematically interrelated.

Worldwide dispersion of the sustainable business models' literature assigned to countries names and number of affiliations are given in Table 3. This analysis is based on data provided by the authors of publications, so the total number of countries does not sum up to 316. Moreover, 7 references cannot be assigned to any country—-the reasons for this were not specified in the Scopus database. Since shift 
towards sustainable business models is crucial to reach Sustainable Development Goals (SDG) [47] adopted by United Nations member states in 2015 [38]), the analysis interrelating the number of publications on sustainable business models per country (approximately comparable with number of affiliations) and countries' SDG Index has been conducted (based on [48]).

Table 3. Worldwide dispersion of the sustainable business models literature, 2002-2020 $(n=316)$.

\begin{tabular}{|c|c|c|c|c|c|}
\hline Country & $\begin{array}{l}\text { Number of } \\
\text { Affiliations }\end{array}$ & $\begin{array}{l}\text { SGD Index } \\
2019\end{array}$ & Country & $\begin{array}{l}\text { Number of } \\
\text { Affiliations }\end{array}$ & $\begin{array}{l}\text { SDG Index } \\
2019\end{array}$ \\
\hline $\begin{array}{l}\text { United } \\
\text { Kingdom }\end{array}$ & 56 & 79.4 & Slovenia & 3 & 79.4 \\
\hline USA & 42 & 74.5 & Taiwan & 3 & N/A \\
\hline Germany & 39 & 81.1 & Lebanon & 2 & 65.7 \\
\hline Netherlands & 39 & 80.4 & Luxembourg & 2 & 74.8 \\
\hline Italy & 29 & 75.8 & New Zealand & 2 & 79.5 \\
\hline Sweden & 24 & 85.0 & Philippines & 2 & 64.9 \\
\hline India & 21 & 61.1 & Puerto Rico & 2 & $\mathrm{~N} / \mathrm{A}$ \\
\hline Australia & 18 & 73.9 & Argentina & 1 & 74.9 \\
\hline Finland & 14 & 82.8 & Bangladesh & 1 & 60.9 \\
\hline France & 14 & 81.5 & Bulgaria & 1 & 74.9 \\
\hline Spain & 14 & 77.8 & Burkina Faso & 1 & 52.4 \\
\hline Canada & 13 & 77.9 & Chile & 1 & 75.6 \\
\hline China & 12 & 73.2 & Croatia & 1 & 77.8 \\
\hline Norway & 12 & 80.7 & Greece & 1 & 71.4 \\
\hline Austria & 9 & 81.1 & Hong Kong & 1 & N/A \\
\hline Brazil & 9 & 70.6 & Indonesia & 1 & 64.2 \\
\hline Switzerland & 7 & 78.8 & Iran & 1 & 70.5 \\
\hline Denmark & 6 & 85.2 & Japan & 1 & 78.9 \\
\hline Portugal & 6 & 76.4 & Latvia & 1 & 77.1 \\
\hline Romania & 6 & 72.7 & Morocco & 1 & 69.1 \\
\hline Belgium & 5 & 78.9 & Nigeria & 1 & 46.4 \\
\hline Lithuania & 5 & 75.1 & Pakistan & 1 & 55.6 \\
\hline South Africa & 5 & 61.5 & Saudi Arabia & 1 & 64.8 \\
\hline Czech Republic & 4 & 80.7 & Senegal & 1 & 57.3 \\
\hline Ireland & 4 & 78.2 & South Korea & 1 & $\mathrm{~N} / \mathrm{A}$ \\
\hline Colombia & 3 & 69.6 & Sudan & 1 & N/A \\
\hline Iceland & 3 & 79.2 & Tunisia & 1 & 70.0 \\
\hline Malaysia & 3 & 69.6 & $\begin{array}{l}\text { United Arab } \\
\text { Emirates }\end{array}$ & 1 & 69.7 \\
\hline Mexico & 3 & 68.5 & $\begin{array}{l}\text { Virgin Islands } \\
\text { (British) }\end{array}$ & 1 & N/A \\
\hline Poland & 3 & 75.9 & Undefined & 7 & N/A \\
\hline $\begin{array}{l}\text { Russian } \\
\text { Federation }\end{array}$ & 3 & 70.9 & & & \\
\hline
\end{tabular}

Note: The Sustainable Development Goals Index 2019 was not available (N/A) for the following countries/dependent territories: Taiwan, Puerto Rico, South Korea, Sudan, and British Virgin Islands. Source: own elaboration based on the Scopus database and [48] (In order to determine the correlation strength of these parameters, the Pearson correlation coefficient including the following criteria were computed (the criteria are defined according to Guilford's interpretation of the magnitude of significant correlations, [49] after [50]): slight, almost no relation, $\left|r_{x y}\right|<0.19$; low correlation, definite but small relation, $0.20 \leq\left|r_{x y}\right|<0.39$; moderate correlation; substantial relation, $0.40 \leq\left|r_{x y}\right|<$ 0.69 ; high correlation; strong relation, $0.70 \leq\left|r_{\mathrm{xy}}\right|<0.89$; very high correlation very dependable relation, $0.90 \leq\left|r_{\mathrm{xy}}\right|<$ 1.00; practically significant relation, $\left|r_{x y}\right| \geq 0.30$.).

The Pearson correlation coefficient for these two sets of data is equal to 0.34 (moderate direct dependence), which means that there is no strong or weak correlation between the number of references per country and the SDG Index, yet some relation exists, and according to mentioned Guilford's interpretation, is a practically significant relation. 


\subsection{Performance Bibliometric Analysis}

One of the ways to measure the influence of publications in a research field is through their citation numbers. To map the general citation structure of analyzed records, publications have been classified to seven groups based on the number of citations obtained. Table 4 presents a general citation structure in sustainable business models' research.

Table 4. General citation structure in sustainable business models research in Scopus.

\begin{tabular}{ccc}
\hline Number of Citations & Number of Papers & Percentage of References \\
\hline$\geq 500$ & 2 & $0.63 \%$ \\
$250 \div 499$ & 4 & $1.27 \%$ \\
$100 \div 249$ & 8 & $2.53 \%$ \\
$50 \div 99$ & 18 & $5.70 \%$ \\
$25 \div 49$ & 38 & $12.03 \%$ \\
$1 \div 24$ & 159 & $50.32 \%$ \\
0 & 87 & $27.53 \%$ \\
\hline
\end{tabular}

Source: own elaboration based on data from the Scopus database.

The majority of documents were cited less than 25 times. Only two papers (less than 1\%) have received more than 500 citations. The highest number of citations (790) was obtained by a review paper [23] (as it is discussed further in the paper). This does not come as a surprise, because review articles are usually the most frequently cited documents. Nevertheless, five out of six highly cited publications on sustainable business models (cited at least 250 times) are research papers $[24,27,29,51]$. The h-index for all of 316 publications is equal to 43 .

Nonetheless appealing is the analysis of citations from the viewpoint of citations' sources, which is given in Table 5. This part of analysis was based on the 20 most highly cited journals in the researched area of sustainable business models. Please note that Table 2 presented the most often chosen journals that publish papers in sustainable business models research indexed in Business, Management and Accounting and Economics, Econometrics and Finance subject areas. It is worth referring to that information and commenting it together with Table 5 , in which contributions were classified according to threshold citations. It is not astounding that by far the most popular choice for publications is the one cited most often-i.e., Journal of Cleaner Production, with 96 publications and 4232 citations, ranked as the first one among most cited and top publishing journals. In fact, four of the top five journals ranked by number of publications are listed among the top 10 most highly cited journals. Organization and Environment with nine publications is the second most referenced journal cited 821 times. Business Strategy and the Environment with the same number of publications is ranked fifth with 304 citations, which means that it is almost three times less cited. The fourth journal is British Food Journal with seven publications and 61 citations, occupying 10th place in the most cited journals ranking. 
Table 5. Most cited journals in sustainable business models' research.

\begin{tabular}{crc}
\hline Rank & Source Title & Cited by Total \\
\hline 1 & Journal of Cleaner Production & 4232 \\
2 & Organization and Environment & 821 \\
3 & Journal of Business Ethics & 396 \\
4 & International Journal of Innovation and Sustainable Development & 341 \\
5 & Business Strategy and the Environment & 304 \\
6 & Corporate Governance (Bingley) & 219 \\
7 & Resources, Conservation and Recycling & 167 \\
8 & International Journal of Innovation Management & 83 \\
9 & Sustainability Accounting, Management and Policy Journal & 65 \\
10 & British Food Journal & 61 \\
11 & Journal of Manufacturing Technology Management & 58 \\
12 & Journal of Management Information Systems & 49 \\
13 & International Journal of Retail E Distribution Management & 48 \\
14 & European Business Review & 47 \\
15 & International Journal of Electronic Commerce & 47 \\
16 & Journal of Media Economics & 46 \\
17 & IIMB Management Review & 42 \\
18 & (Indian Institute of Management Bangalore Management Review) & 41 \\
19 & Industrial Management and Data Systems & 40 \\
20 & International Journal of Entrepreneurial Behaviour and Research & 40 \\
\hline
\end{tabular}

Source: own elaboration based on data from the Scopus database.

In order to further map the research stream devoted to sustainable business models and identify the most substantial contributors to the advances of the research area, the authors of the current article suggest indicator-based analysis aimed at studying the most influential and high-impact authors, journals, and papers. Usually indicators consider the ratio of papers' citations understood as certain number citations divided by certain number of publications) and particular number of publications above a threshold citation ([52,53] given here after [42]). However, this analysis is based on the ratio $i_{j}$ developed as Equations (1)-(3).

$$
\begin{gathered}
i_{j}=c_{J}^{\Sigma} / p_{J}^{\Sigma} ; \quad j \in J, \quad J=\{j: j=\overline{1, J}\} \\
c_{J}^{\Sigma}=\sum_{1}^{J} c_{j} ; \quad j \in J, \quad J=\{j: j=\overline{1, J}\} \\
p_{J}^{\Sigma}=\sum_{1}^{J} p_{j} ; \quad j \in J, \quad J=\{j: j=\overline{1, J}\}
\end{gathered}
$$

where:

$J$-set of all analyzed sources,

$i_{j}$-ratio of influence of an analyzed research topic computed for $j$ th source,

$c_{j}$-number of citations for an analyzed research topic in $j$ th source,

$p_{j}$-number of publications in an analyzed research topic in $j$ th source,

$c_{J}^{\Sigma}$ — total number of citations for an analyzed research topic in all $J$ analyzed sources,

$i$ c - ratio of citations for analyzed research topic in $j$ th source and a total number of citations in all $J$ analyzed sources,

$p_{J}^{\Sigma}$ — total number of publications in an analyzed research topic in all $J$ analyzed sources,

$i_{j}^{p}$-ratio of publications in an analyzed research topic in $j$ th source and a total number of publications in all $J$ analyzed sources.

The mentioned ratio of influence for an analyzed research topic computed for $j$ th source and elementary parameters, including numbers of citations and publications, are given for certain source 
titles in Table 6. Moreover, the equations use the following value parameters not mentioned directly in Table 6, i.e., $c_{J}^{\Sigma}$ is equal to 7891 citations in current analysis, whereas $p_{J}^{\Sigma}$ is equal to 316 publications. Table 6 is categorized based on the values of ratios of influence of the sustainable business model research topic computed for $j$ th source. The analysis proves that the highest influence is not computed for the journal with the highest numbers of citations and publications. This is not surprising considering the fact that e.g., for source title $j=1$ (International Journal of Innovation and Sustainable Development), there was only one publication with 341 citation, whereas in the case of the source title $j=9$ (Journal of Cleaner Production) with the highest numbers of citations and publications, the average value for straightforward ratio of citations per number of publications is relatively low with 44 items only (4232 citations divided by 96 publications are equal to 44 citations per publication).

Table 6. High impact journals in sustainable business models research.

\begin{tabular}{|c|c|c|c|c|c|c|c|c|c|}
\hline$j$ & Source Title & $c_{j}$ & $p_{j}$ & $i_{j}^{c}$ & $i_{j}^{p}$ & $i_{j}$ & $S N I P_{j}$ & $S J R_{j}$ & Scopus Coverage Years \\
\hline 1 & $\begin{array}{c}\text { International Journal of } \\
\text { Innovation and Sustainable } \\
\text { Development }\end{array}$ & 341 & 1 & 0.043 & 0.003 & 13.656 & 0.519 & 0.196 & from 2005 to present \\
\hline 2 & Journal of Business Ethics & 396 & 4 & 0.050 & 0.013 & 3.965 & N/A & N/A & $\begin{array}{c}1979,1985 \text {, from } 1990 \text { to } \\
\text { 1993, 1996, from } 1998 \text { to } \\
\text { 1999, 2001, from } 2018\end{array}$ \\
\hline 3 & $\begin{array}{l}\text { Organization and } \\
\text { Environment }\end{array}$ & 821 & 9 & 0.104 & 0.028 & 3.653 & 2.609 & 2.605 & from 1987 to present \\
\hline 4 & $\begin{array}{c}\text { Corporate Governance } \\
\text { (Bingley) }\end{array}$ & 219 & 3 & 0.028 & 0.010 & 2.923 & 1.114 & 0.430 & from 2001 to present \\
\hline 5 & $\begin{array}{l}\text { J. of Manufacturing } \\
\text { Technology Management }\end{array}$ & 58 & 1 & 0.007 & 0.003 & 2.323 & 0.420 & 0.228 & from 2000 to present \\
\hline 6 & $\begin{array}{l}\text { Resources, Conservation and } \\
\text { Recycling }\end{array}$ & 167 & 3 & 0.021 & 0.010 & 2.230 & 2.258 & 1.541 & from 1988 to present \\
\hline 7 & $\begin{array}{l}\text { International J. of Retail \& } \\
\text { Distribution Management }\end{array}$ & 48 & 1 & 0.006 & 0.003 & 1.922 & 1.040 & 0.767 & from 1990 to present \\
\hline 8 & $\begin{array}{c}\text { International J. of Electronic } \\
\text { Commerce }\end{array}$ & 47 & 1 & 0.006 & 0.003 & 1.882 & 1.285 & 1,634 & from 1996 to present \\
\hline 9 & $\begin{array}{l}\text { Journal of Cleaner } \\
\text { Production }\end{array}$ & 4232 & 96 & 0.537 & 0.304 & 1.765 & 2.308 & 1.620 & from 1993 to resent \\
\hline 10 & $\begin{array}{l}\text { International J. of Innovation } \\
\text { Manag. }\end{array}$ & 83 & 2 & 0.011 & 0.006 & 1.662 & 0.554 & 0.389 & from 2008 to present \\
\hline 11 & $\begin{array}{l}\text { Manufacturing and Service } \\
\text { Operations Management }\end{array}$ & 40 & 1 & 0.005 & 0.003 & 1.602 & 1.969 & 4.439 & from 1999 to present \\
\hline 12 & $\begin{array}{l}\text { Accounting, Auditing and } \\
\text { Accountability J. }\end{array}$ & 37 & 1 & 0.005 & 0.003 & 1.482 & 1.563 & 1.456 & from 1988 to present \\
\hline 13 & $\begin{array}{c}\text { Baltic Journal of } \\
\text { Management }\end{array}$ & 34 & 1 & 0.004 & 0.003 & 1.362 & 1.117 & 0.481 & from 2006 to present \\
\hline 14 & $\begin{array}{c}\text { Journal of Supply Chain } \\
\text { Management }\end{array}$ & 34 & 1 & 0.004 & 0.003 & 1.362 & N/A & N/A & 2018 \\
\hline 15 & $\begin{array}{c}\text { Business Strategy and the } \\
\text { Environment }\end{array}$ & 304 & 9 & 0.039 & 0.029 & 1.353 & 2.488 & 2.166 & from 1992 to present \\
\hline 16 & $\begin{array}{c}\text { Production Planning and } \\
\text { Control }\end{array}$ & 33 & 1 & 0.004 & 0.003 & 1.322 & 1.514 & 1.427 & from 1990 to present \\
\hline 17 & Supply Chain Management & 30 & 1 & 0.004 & 0.003 & 1.201 & 2.018 & 2.103 & from 1996 to present \\
\hline 18 & $\begin{array}{c}\text { Journal of Intellectual } \\
\text { Capital }\end{array}$ & 27 & 1 & 0.003 & 0.003 & 1.081 & 2.055 & 1.294 & from 2000 to present \\
\hline 19 & $\begin{array}{l}\text { J. of Management } \\
\text { Information Systems }\end{array}$ & 49 & 2 & 0.006 & 0.006 & 0.981 & N/A & N/A & from 1984 to 1991 \\
\hline 20 & European Business Review & 47 & 2 & 0.006 & 0.006 & 0.941 & 0.893 & 0.497 & $\begin{array}{l}\text { 1970, from } 1989 \text { to } \\
\text { present }\end{array}$ \\
\hline
\end{tabular}

Source: own elaboration based on data from the Scopus database (N/A-data not available).

The research curiosity led the authors to analyze if there is any dependency between the elaborated ratio of influence and bibliographic indicators computed directly in the considered database, i.e., SNIP, which measures contextual citation impact by weighting citations based on the total number of citations in a subject area using the Scopus data [54], and SJR, which stands for SCImago Journal Rank and measures weighted citations received by a serialized source title-citation weighting depends 
on subject area and prestige of a citing serial [55]. This analysis should be conducted keeping in mind certain research limitations related to coverage years of indexing sources in a database. Since source titles $j=\{1,2,10,13,14,19\}$ do not cover the complete period of this analyses $(2002 \div 2020)$, these where excluded from the following analysis. Table 6 presents SNIP 2018 (Source Normalized Impact per Paper in 2018; computed on 30 April 2019) and SJR 2018 (SCImago Journal Rank per 2018; computed on 30 April 2019). No strong correlations between the pairs of a ratio of influence $i_{j}$ and mentioned bibliographic indicators were observed. The Pearson correlation coefficient between a set of data for $i_{j}$ and SNIP is equal to $r\left(i_{j} ; S N I P_{j}\right)=0.069$ and between a set of data for $i_{j}$ and SJR is equal to $r\left(i_{j} ; S J R_{j}\right)=-0.010$. This allows to conclude that such a ratio of influence could be successfully used for quantitative and qualitative evaluations of publications, especially because there is continuously an intense debate on the indicators that assess journal quality [56].

Table 7 presents publications of greatest researchers' interest listed with regards to their number of citations. Interestingly, among 20 most often cited papers, there is only one review (with the highest overall number of citations [23]), 19 articles and no conference papers. Only one paper among these contributions was published in 2008, whereas most of the papers were published since 2012 onwards. This is not surprising when comparing Table 7 with Figure 3, which presents dynamics of scientific research on sustainable business models developed overtime. Moreover, it is worth noting that the first papers published in the researched area have relatively low numbers of citations, i.e., [5] with 47 citations (the paper was published in 2002, however, in the database it is indexed under 2003), [4] with 0 citations and the paper of Høgevold N.M. from 2003 with 13 citations (the reference is not included in the references list due to the misleading information in the database-incorrect year and the source title: Høgevold, N.M., 2003, A corporate effort towards a sustainable business model: A case study from the Norwegian furniture industry. International Journal of Operations and Production Management, 23(4), 392-400.). There may be several reasons for this, for example the third of the mentioned papers is industry-specific (furniture industry). However, deeper analyses showed that the paper by Høgevold N.M. is incorrectly indexed in the database. The correct one is [57] with 41 citations. Due to the fact that such errors in source indexing may also occur in regards to other sources, the authors of this article have decided to treat them within the limits of the error and have not decided to verify the other articles (it is assumed that errors in the database are so rare that they can be ignored).

Table 7. Most cited papers in sustainable business models' research.

\begin{tabular}{|c|c|c|c|c|c|c|}
\hline Rank & Authors & Contribution Title & Source Title & $\begin{array}{l}\text { Number of } \\
\text { Citations }\end{array}$ & Year & $\begin{array}{c}\text { Type of } \\
\text { Contribution }\end{array}$ \\
\hline 1 & $\begin{array}{l}\text { Bocken, N.M.P.; } \\
\text { Short, S.W.; Rana } \\
\text { P.; Evans, S. [23] }\end{array}$ & $\begin{array}{c}\text { A literature and practice review } \\
\text { to develop sustainable business } \\
\text { model archetypes. }\end{array}$ & $\begin{array}{l}\text { Journal of Cleaner } \\
\quad \text { Production }\end{array}$ & 790 & 2014 & Review \\
\hline 2 & $\begin{array}{c}\text { Boons, F.; } \\
\text { Lüdeke-Freund, F. } \\
\text { [9] }\end{array}$ & $\begin{array}{c}\text { Business models for } \\
\text { sustainable innovation: } \\
\text { state-of-the-art and steps } \\
\text { towards a research agenda. }\end{array}$ & $\begin{array}{l}\text { Journal of Cleaner } \\
\quad \text { Production }\end{array}$ & 629 & 2013 & Article \\
\hline 3 & $\begin{array}{c}\text { Stubbs, W.; } \\
\text { Cocklin, C. [29] }\end{array}$ & $\begin{array}{c}\text { Conceptualizing a } \\
\text { "sustainability business model" }\end{array}$ & $\begin{array}{l}\text { Organization and } \\
\text { Environment }\end{array}$ & 379 & 2008 & Article \\
\hline 4 & $\begin{array}{c}\text { Boons, F.; } \\
\text { Montalvo, C.; } \\
\text { Quist, J.; Wagner, } \\
\text { M. [24] }\end{array}$ & $\begin{array}{c}\text { Sustainable innovation, } \\
\text { business models and economic } \\
\text { performance: An overview }\end{array}$ & $\begin{array}{l}\text { Journal of Cleaner } \\
\quad \text { Production }\end{array}$ & 353 & 2013 & Article \\
\hline 5 & $\begin{array}{l}\text { Murray, A.; Skene, } \\
\text { K.; Haynes, K. [51] }\end{array}$ & $\begin{array}{l}\text { The circular economy: an } \\
\text { interdisciplinary exploration of } \\
\text { the concept and application in } \\
\text { a global context. }\end{array}$ & $\begin{array}{c}\text { Journal of Business } \\
\text { Ethics }\end{array}$ & 350 & 2017 & Article \\
\hline 6 & $\begin{array}{l}\text { Schaltegger, S.; } \\
\text { Lüdeke-Freund, F.; } \\
\text { Hansen, E.G. [27] }\end{array}$ & $\begin{array}{l}\text { Business cases for } \\
\text { sustainability: The role of } \\
\text { business model innovation for } \\
\text { corporate sustainability. }\end{array}$ & $\begin{array}{l}\text { International Journal of } \\
\text { Innovation and } \\
\text { Sustainable } \\
\text { Development }\end{array}$ & 341 & 2012 & Article \\
\hline 7 & $\begin{array}{l}\text { Bocken, N.; Short, } \\
\text { S.; Rana, P.; Evans, } \\
\text { S. [25] }\end{array}$ & $\begin{array}{l}\text { A value mapping tool for } \\
\text { sustainable business modelling. }\end{array}$ & $\begin{array}{l}\text { Corporate Governance } \\
\text { (Bingley) }\end{array}$ & 179 & 2013 & Article \\
\hline
\end{tabular}


Table 7. Cont.

\begin{tabular}{|c|c|c|c|c|c|c|}
\hline Rank & Authors & Contribution Title & Source Title & $\begin{array}{l}\text { Number of } \\
\text { Citations }\end{array}$ & Year & $\begin{array}{c}\text { Type of } \\
\text { Contribution }\end{array}$ \\
\hline 8 & $\begin{array}{l}\text { Tseng, M.-L.; Chiu, } \\
\text { A.S.F.; Tan, R.R.; } \\
\text { Siriban-Manalang, } \\
\text { A.B. [58] }\end{array}$ & $\begin{array}{l}\text { Sustainable consumption and } \\
\text { production for Asia: } \\
\text { Sustainability through green } \\
\text { design and practice. }\end{array}$ & $\begin{array}{l}\text { Journal of Cleaner } \\
\text { Production }\end{array}$ & 177 & 2013 & Article \\
\hline 9 & $\begin{array}{l}\text { Witjes, S.; Lozano, } \\
\text { R. [59] }\end{array}$ & $\begin{array}{l}\text { Towards a more circular } \\
\text { economy: proposing a } \\
\text { framework linking sustainable } \\
\text { public procurement and } \\
\text { sustainable business models. }\end{array}$ & $\begin{array}{l}\text { Resources, Conservation } \\
\text { and Recycling }\end{array}$ & 159 & 2016 & Article \\
\hline 10 & $\begin{array}{l}\text { Joyce, A.; Paquin, } \\
\text { R.L. [60] }\end{array}$ & $\begin{array}{l}\text { The triple layered business } \\
\text { model canvas: A tool to design } \\
\text { more sustainable business } \\
\text { models }\end{array}$ & $\begin{array}{l}\text { Journal of Cleaner } \\
\quad \text { Production }\end{array}$ & 158 & 2016 & Article \\
\hline 11 & $\begin{array}{c}\text { Evans, S.; } \\
\text { Vladimirova, D.; } \\
\text { Holgado, M.; Van } \\
\text { Fossen, K.; Yang, } \\
\text { M.; Silva, E.A.; } \\
\text { Barlow, C.Y. [18] }\end{array}$ & $\begin{array}{l}\text { Business model innovation for } \\
\text { sustainability: towards a } \\
\text { unified perspective for creation } \\
\text { of sustainable business models. }\end{array}$ & $\begin{array}{l}\text { Business Strategy and } \\
\text { the Environment }\end{array}$ & 134 & 2017 & Article \\
\hline 12 & $\begin{array}{c}\text { Matos, S.; } \\
\text { Silvestre, B.S. [61] }\end{array}$ & $\begin{array}{l}\text { Managing stakeholder relations } \\
\text { when developing sustainable } \\
\text { business models: The case of } \\
\text { the Brazilian energy sector }\end{array}$ & $\begin{array}{l}\text { Journal of Cleaner } \\
\quad \text { Production }\end{array}$ & 130 & 2013 & Article \\
\hline 13 & $\begin{array}{l}\text { Schaltegger, S.; } \\
\text { Lüdeke-Freund, F.; } \\
\text { Hansen, E.G. [21] }\end{array}$ & $\begin{array}{l}\text { Business models for } \\
\text { sustainability: a } \\
\text { co-evolutionary analysis of } \\
\text { sustainable entrepreneurship, } \\
\text { innovation, and } \\
\text { transformation. }\end{array}$ & $\begin{array}{l}\text { Organization and } \\
\text { Environment }\end{array}$ & 125 & 2016 & Article \\
\hline 14 & $\begin{array}{l}\text { Upward, A.; Jones, } \\
\text { P. [8] }\end{array}$ & $\begin{array}{l}\text { An ontology for strongly } \\
\text { sustainable business models: } \\
\text { defining an enterprise } \\
\text { framework compatible with } \\
\text { natural and social science. }\end{array}$ & $\begin{array}{l}\text { Organization and } \\
\text { Environment }\end{array}$ & 123 & 2016 & Article \\
\hline 15 & $\begin{array}{l}\text { Scheepens, A.E.; } \\
\text { Vogtländer, J.G.; } \\
\text { Brezet, J.C. [62] }\end{array}$ & $\begin{array}{l}\text { Two life cycle assessment } \\
\text { (LCA)-based methods to } \\
\text { analyse and design complex } \\
\text { (regional) circular economy } \\
\text { systems. Case: making water } \\
\text { tourism more sustainable. }\end{array}$ & $\begin{array}{l}\text { Journal of Cleaner } \\
\quad \text { Production }\end{array}$ & 91 & 2016 & Article \\
\hline 16 & $\begin{array}{l}\text { Geissdoerfer, M.; } \\
\text { Morioka, S.N.; de } \\
\text { Carvalho, M.M.; } \\
\text { Evans, S. [35] }\end{array}$ & $\begin{array}{l}\text { Business models and supply } \\
\text { chains for the circular economy. }\end{array}$ & $\begin{array}{l}\text { Journal of Cleaner } \\
\quad \text { Production }\end{array}$ & 88 & 2018 & Article \\
\hline 17 & $\begin{array}{l}\text { Abdelkafi, N.; } \\
\text { Täuscher, K. [13] }\end{array}$ & $\begin{array}{l}\text { Business models for } \\
\text { sustainability from a system } \\
\text { dynamics perspective. }\end{array}$ & $\begin{array}{l}\text { Organization and } \\
\text { Environment }\end{array}$ & 85 & 2016 & Article \\
\hline 18 & $\begin{array}{l}\text { Geissdoerfer, M.; } \\
\text { Bocken, N.M.P.; } \\
\text { Hultink, E.J. [22] }\end{array}$ & $\begin{array}{l}\text { Design thinking to enhance the } \\
\text { sustainable business modelling } \\
\text { process-a workshop based on } \\
\text { a value mapping process. }\end{array}$ & $\begin{array}{l}\text { Journal of Cleaner } \\
\quad \text { Production }\end{array}$ & 78 & 2016 & Article \\
\hline 19 & $\begin{array}{l}\text { Rauter, R.; Jonker, } \\
\text { J.; Baumgartner, } \\
\text { R.J. [19] }\end{array}$ & $\begin{array}{l}\text { Going one's own way: drivers } \\
\text { in developing business models } \\
\text { for sustainability. }\end{array}$ & $\begin{array}{l}\text { Journal of Cleaner } \\
\quad \text { Production }\end{array}$ & 75 & 2017 & Article \\
\hline 20 & $\begin{array}{l}\text { Yang, M.; Evans, } \\
\text { S.; Vladimirova, } \\
\text { D.; Rana, P. [63] }\end{array}$ & $\begin{array}{l}\text { Value uncaptured perspective } \\
\text { for sustainable business model } \\
\text { innovation. }\end{array}$ & $\begin{array}{l}\text { Journal of Cleaner } \\
\quad \text { Production }\end{array}$ & 73 & 2017 & Article \\
\hline
\end{tabular}

Source: own elaboration based on data from the Scopus database.

Table 7 presents the most cited papers in sustainable business models' research. Such approach to the analysis of papers' influence in a given research area is valuable, however, it has some serious limitations. The number of citations is determined by many factors including, among others, the time of its availability on the research market. The longer a paper is available, the more citations it can possibly gain. An in-depth approach is necessary to discover how influential are papers on sustainable business models. Such analysis should take into account not only citations, but also a period of time of publications' availability. One of the possible ways to compile a list of most influential publications in a given research area is to include a coefficient of a number of citations per year, given as Equation (4). 
The denominator of the Equation (4) includes minus 1 year due to the fact that particular publications could be published in the different months or quarters of a certain year and still might receive some citations in that year.

$$
c_{p}^{Y}=\left\lfloor\frac{c_{p}}{\left(y_{c}-y_{p}-1\right)}\right\rfloor ; p \in \boldsymbol{P}, \boldsymbol{P}=\{j: j=\overline{1, P}\}
$$

where:

$P$ - set of all analyzed publications,

$c_{p}^{Y}$-weighted coefficient of a number of citations per year in $p$ th publication,

$c_{p}$-number of total citations of $p$ th publication,

$y_{c}$-year's attribute equal to the current year according to the Gregorian calendar,

$y_{p}$-year of $p$ th publication release according to the Gregorian calendar.

Whereas Table 7 ranks publications according to their total citations, Table 8 presents a ranking according to $c_{p}^{Y}$ parameter. The first paper with the highest number of citations, i.e., [23], is ranked in the highest position in the ranking of $c_{p}^{Y}$ parameter as well. However, for example, the publication given in the fifth row in Table 7 with 350 total citations, i.e., [51], is the second most important paper when it comes to high-impact contributions to the body of knowledge on sustainable business models. Comparing both tables allows to draw some important conclusions about the research on sustainable business models. Although, high-impact papers constitute a different ranking than highly cited papers, it is worth underlining that most of the latter ones are still contributions of high importance (see Table 8, column Rank according to $c_{p}$ ).

Table 8. High-impact papers in sustainable business models' research (20 highest evaluated papers).

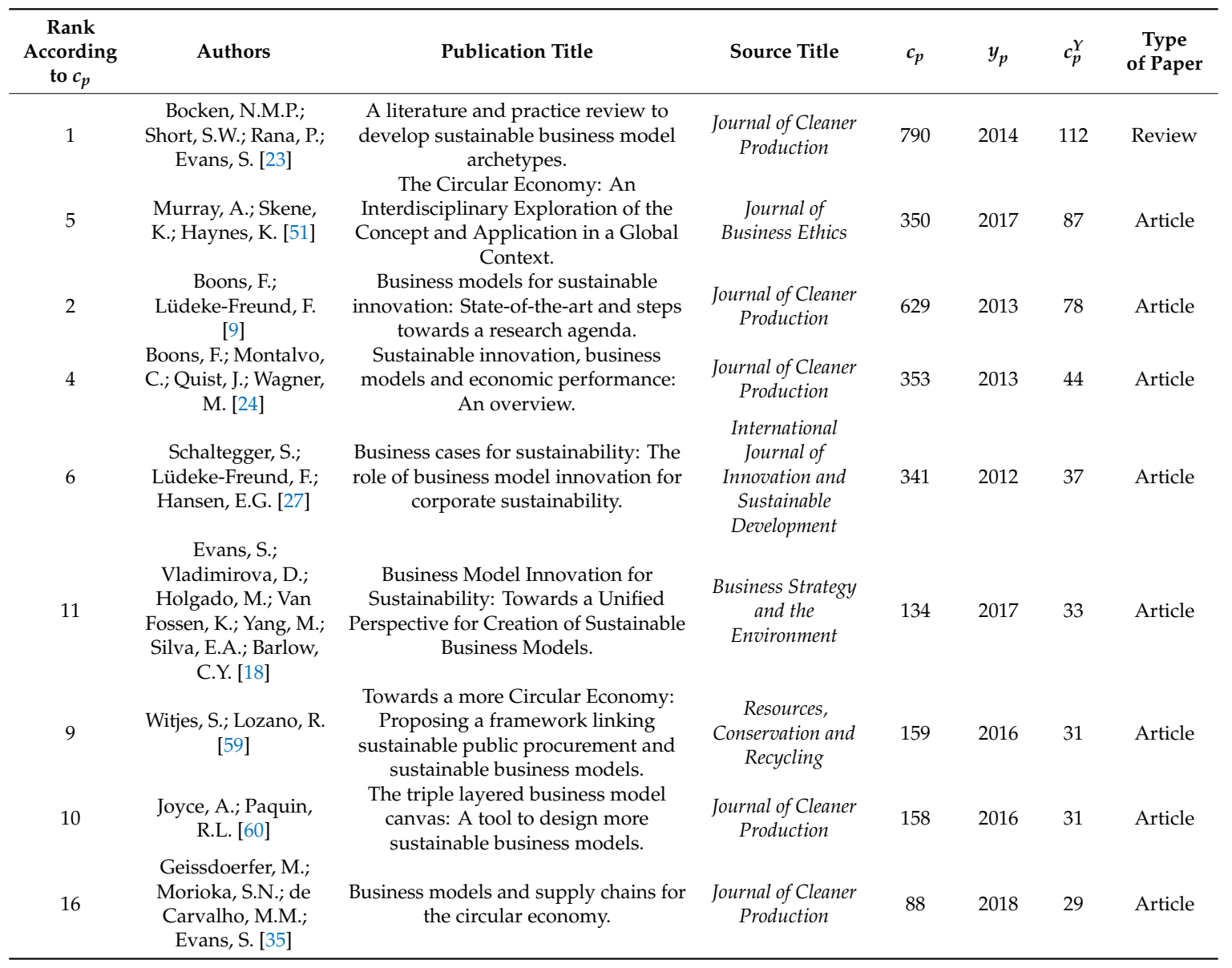


Table 8. Cont.

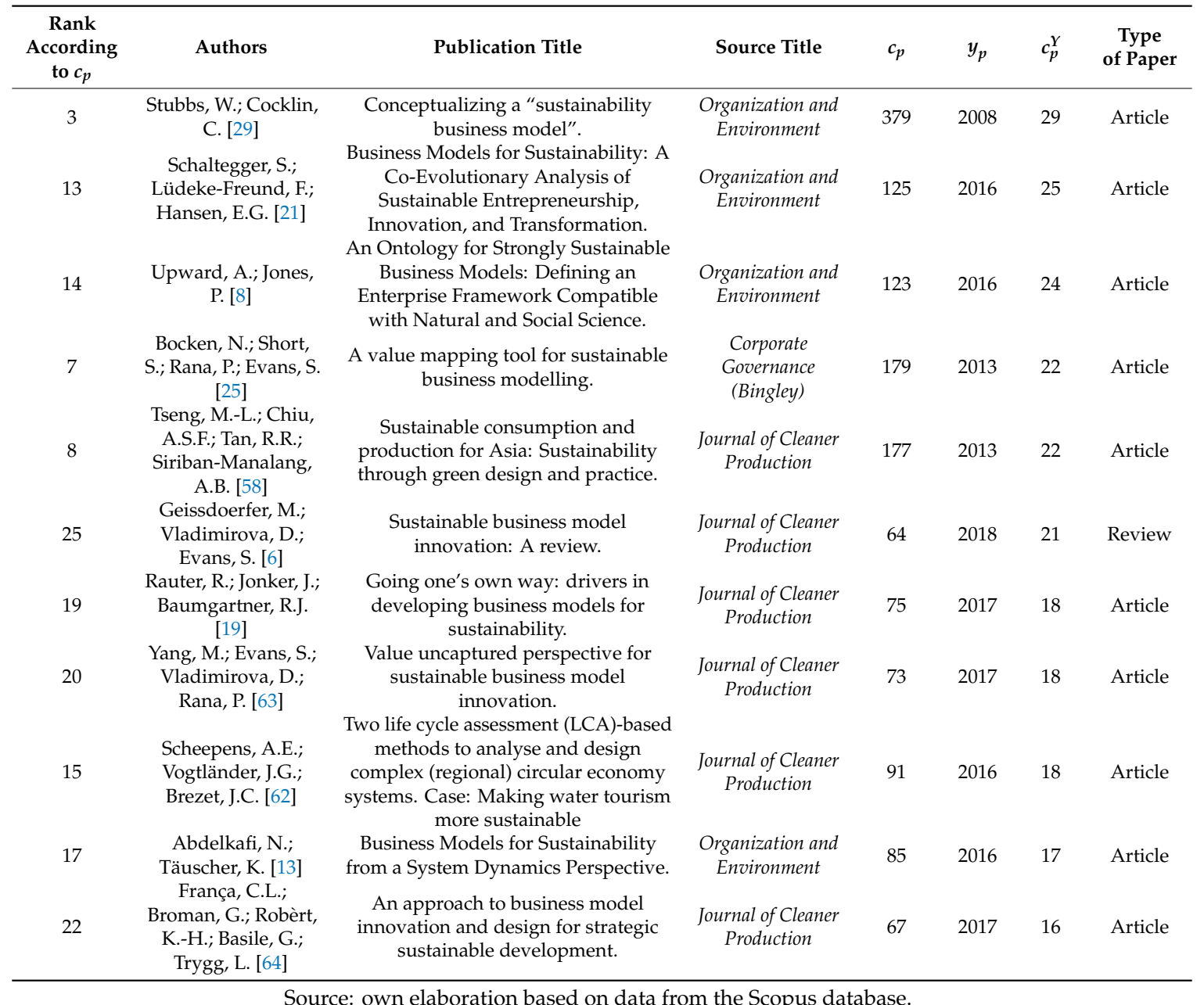

Source: own elaboration based on data from the Scopus database.

Interesting conclusions can also be drawn from the analysis of researchers elaborating on sustainable business models when it comes to their productivity and influence on research market. Seven-hundred-and-twenty-seven researchers made their contributions to the body of knowledge on sustainable business models in the analyzed period of time (it should be noted that information on authors of two publications were not available in the database-these were conference reviews). Their achievements are presented in Tables 9 and 10, where authors are ranked according to number of citations (Table 9) and number of publications in the researched area (Table 10).

Table 9. Most cited authors in sustainable business models' research.

\begin{tabular}{cccccc}
\hline Authors & $\begin{array}{c}\text { Number } \\
\text { of Papers }\end{array}$ & $\begin{array}{c}\text { Number of } \\
\text { Citations }\end{array}$ & Authors & $\begin{array}{c}\text { Number } \\
\text { of Papers }\end{array}$ & $\begin{array}{c}\text { Number of } \\
\text { Citations }\end{array}$ \\
\hline Evans, S. & 9 & 1367 & Montalvo, C. & 1 & 353 \\
Bocken, N.M.P. & 15 & 1363 & Quist, J. & 1 & 353 \\
Lüdeke-Freund, F. & 7 & 1203 & Wagner, M. & 1 & 353 \\
Rana, P. & 3 & 1042 & Haynes, K. & 1 & 350 \\
Boons, F. & 3 & 999 & Murray, A. & 1 & 350 \\
Short, S.W. & 1 & 790 & Skene, K. & 1 & 350 \\
Schaltegger, S. & 4 & 478 & Vladimirova, D. & 3 & 271 \\
Hansen, E.G. & 3 & 466 & Geissdoerfer, M. & 3 & 230 \\
Stubbs, W. & 4 & 419 & Yang, M. & 3 & 214 \\
Cocklin, C. & 1 & 379 & Short, S. & 1 & 179 \\
\hline
\end{tabular}

Source: own elaboration based on data from the Scopus database. 
Table 10. Most productive authors in sustainable business models' research (considering the total number of publications per author).

\begin{tabular}{ccc}
\hline Authors & Number of Papers & Number of Citations \\
\hline Bocken, N.M.P. & 15 & 1363 \\
Evans, S. & 9 & 1367 \\
Lüdeke-Freund, F. & 7 & 1203 \\
Svensson, G. & 7 & 98 \\
Høgevold, N.M. & 6 & 120 \\
Padin, C. & 5 & 68 \\
Schaltegger, S. & 4 & 478 \\
Stubbs, W. & 4 & 419 \\
Baldassarre, B. & 4 & 100 \\
Goyal, S. & 4 & 72 \\
\hline
\end{tabular}

Source: own elaboration based on data from the Scopus database.

In general, it can be concluded that Evans S. and Bocken N.M.P. are the most influential and productive authors in sustainable business models' research. Their numbers of citations are similar in terms of value (Table 9), however, the difference in number of published papers cannot be treated approximately. Moreover, they are also co-authoring certain papers, which surely helped them to secure their top position in this research field. Interestingly, among most cited authors there are relatively many researchers who published only one paper on sustainable business models. This leads to the conclusion that the number of papers published by an author in the research field is not positively correlated with their citation ratio, nevertheless, this conclusion does not seem to be surprising.

High impact papers tend to focus on three main general topics: (1) sustainable business models and corporate sustainability, (2) sustainable business models and value creation, (3) sustainable business models and circular economy. Certainly, each paper concentrates on a different research problem, analyzed from a different perspective (e.g., business model design, value uncaptured, competitiveness, firm-level sustainability, eco-costs, socially desirable value). However, looking at the impact of the paper assessed based on $c_{p}^{Y}$ parameter, it can be concluded that scholars are interested in further investigating these topics.

\subsection{Bibliometric Mapping of the Sustainable Business Models' Research}

The research results presented above can be supplemented by mapping interrelations between the analyzed bibliometric data, i.e., co-citation of sources, co-citation of authors, bibliographic coupling of countries and co-occurrence of keywords. It allows to present and analyze the most representative connections between the elements that are related to the research area. In [42], the authors considered graphic mapping as an important methodology in the field of bibliometric analyses. They claimed that graphic mapping allows to analyze the intellectual connections within a field of dynamically changing scientific knowledge. Visualization in the graph mapping is represented by a network of elements, in which the size of the node varies according to the importance of a particular element, while the network connections represent how close the connector between the elements is.

The graph mapping is based on graph theory. A graph is a pair given as Equation (5), where $V$ is a set, in which elements are called vertices (singular: vertex), and $E$ is a set of connectors between vertices, whose elements are called edges (sometimes links or lines). In graph mapping, vertex is also known as a node, whereas edge is a connector. Moreover, the graphs in graph mapping are undirected ones. The graph mapping methodology is used in VOSviewer software [65], which was applied in order to conduct this analysis on sustainable business models body of knowledge.

$$
\boldsymbol{G}=(\boldsymbol{V}, \boldsymbol{E})
$$


After such an introduction, it is worthwhile to continue the considerations concerning the productivity of researchers. The productivity of researchers is understood here as co-citation of authors. The authors who have received the highest number of citations in the area of sustainable business models were analyzed. There are 32 nodes in the graph shown in Figure 5, which presents co-citations of researchers whose minimum number of citations is equal to 60 -each researcher is assigned to one node. The larger the diameter of a particular node is in Figure 5, the higher the number of citations was. It can be observed based on the productivity of Bockens N.M.P. (the diameter of the node that is assigned to this researcher is the biggest one), who can be characterized with the highest number of co-authorship publications (as it is confirmed in Table 10, Bockens N.M.P. is the (co-)author of the highest number of publications), and is one of the most often quoted among researchers in sustainable business models research (together with Evans S., who is ranked first in Table 9 and has only four citations more than Bockens N.M.P.). Both researchers together with two more co-authors published a fundamental review on sustainable business models categorizing their archetypes [23], which is respected in the scientific community (790 citations as it is given in Table 8). This is one of the factors that publications of Bockens N.M.P. and Evans S. as a result are the most frequently cited documents in the researched field. Further analyses of the graphical mapping allowed to state that the most powerful players in the sustainable business model research are: Bocken N.M.P., Lüdeke-Freund F., Boons F. and Zott C. (method fractionalization was used in VOSviewer software in that part of the study). They are assigned as leaders of clusters in the graphic mapping analysis and this means that they focus other authors around their research, therefore, their publications are most often cited. It can be stated that on the one hand there is a sort of cooperation between the authors presented in Figure 5 in terms of mutual quotation. However, on the other hand such a situation is connected with yet a small number of publications in the sustainable business models research area.

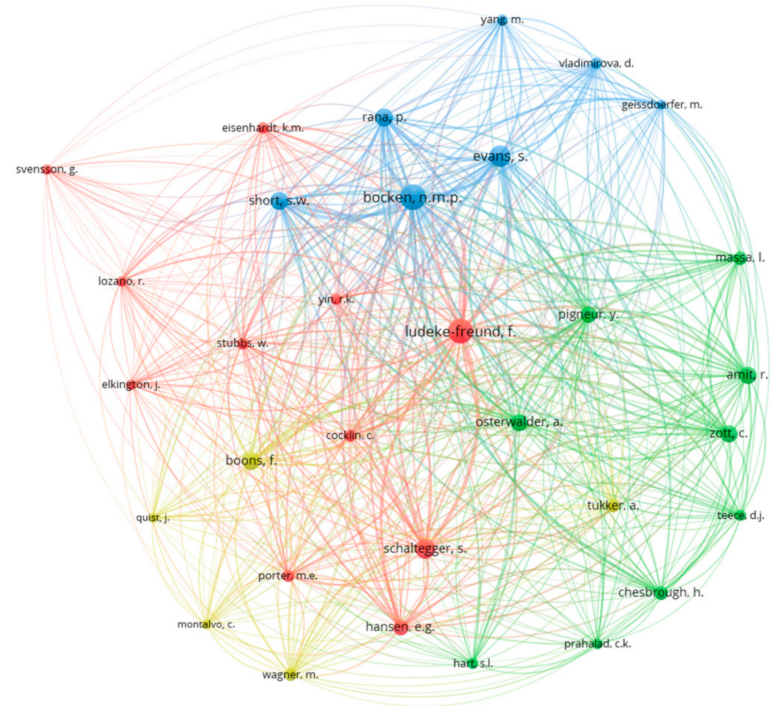

Figure 5. Co-citation of researchers cited in sustainable business models research. Source: own elaboration based on the VOSviewer software.

The sustainable business models research area has grown rapidly in recent decades as it can be concluded based on Figures 2 and 3 and Tables 5-8, and evidence of the phenomena associated with mentioned research area is enthusiastically analyzed in many countries all over the world. Nevertheless, the main aspects of this field are concentrated in a small amount of countries mentioned in Figure 6. These countries are treated in this paper as the most productive countries of the sustainable business models research area, using a bibliographic coupling analysis with a threshold of minimum five publications per country and without limitations in citations number, i.e., minimum number of citations per country is equal to zero. 


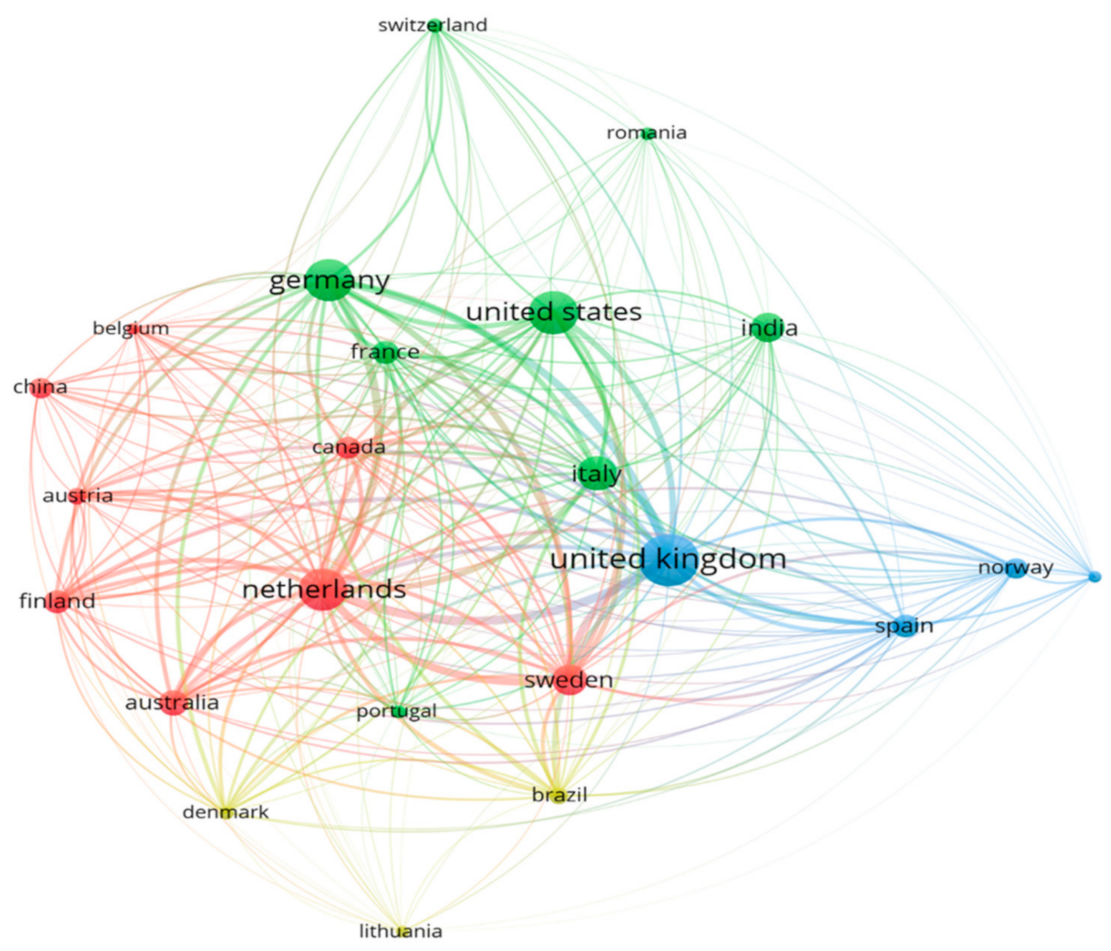

Figure 6. Bibliographic coupling of countries that publish in sustainable business models research. Source: own elaboration based on the VOSviewer software.

It is worth noting that Table 3, which presents worldwide dispersion of the sustainable business models literature for analyzed period of time (expressed in the number of affiliations), is comparable with the results obtained for graph mapping countries that publish in sustainable business models research, i.e., the results of the study given in Figure 6 are consistent with those observed in Table 3 . All the countries mentioned in Figure 6 are characterized with relatively high number of publications and high number of affiliations (five per each of these two parameters) and among these countries are: United Kingdom, United States of America, Germany, Netherlands, Italy, Sweden, India, Australia, Finland, France, Spain, Canada, China, Norway, Austria, Brazil, Switzerland, Denmark, Portugal, Romania, Belgium, Lithuania, and South Africa. It is clear that United Kingdom, United States of America, Germany, and Netherlands lead the research area extensively-these countries are positioned in the center of each group (cluster) in the Figure 6 and are strongly connected to the rest of the countries given in this graph mapping result. A strong presence of European countries can be observed, which means that researchers from these countries are significantly involved with the studied research area.

Data presented in Table 3 and in Figure 6 prove that scholars affiliated to institutions located in the United Kingdom are the ones most focused on the topic of sustainable business models. Thus, it is not surprising that there are four institutions representing England among the institutions that published more than three papers on the analyzed topic (i.e., University of Cambridge-14 papers; University of Manchester-4 papers; Imperial College London—4 papers; University of Hertfordshire—4 papers). However, Delft University of Technology located in the Netherlands, which occupies fourth position in the general ranking, affiliates the highest overall number of papers on sustainable business models (17). There are also three other institutions in the Netherlands focused on the topic with four publications affiliated each, i.e., Vrije Universiteit Amsterdam, Radboud Universiteit in Nijmegen and Universiteit Twente. Sweden is the only country in which research on sustainable business models is concentrated within two institutions, with 11 publications affiliated to Lunds Universitet, 9 publications to The International Institute for Industrial Environmental Economics of Lunds Universitet (which makes it 20 altogether affiliated to Lunds Universitet) and 4 to Högskolan i Borås. Publications affiliated to 
other countries with significant numbers of contributions to the topic are published by scholars located in various institutions.

Interestingly, many of the scholars affiliated in the institutions listed above collaborate and perform research together. Thus, it is hard to find specific research topics that could be associated with a certain research institution. However, looking at most important research trends identified based on analysis of keywords listed in the papers published by the three most productive institutions (i.e., Technische Universiteit Delft, University of Cambridge and Lunds Universitet), there are three main areas of focus: (1) sustainable business models and innovation, (2) sustainable business models and circular economy, (3) sustainable business models and value creation.

Another graphic mapping result is connected to the co-citation structure of source titles (practically journals and conference proceedings) in the analyzed research area. This allows analyzing those journals that have received a greater number of citations in the sustainable business models research area-the minimum number of citations for this part of study were set as 50 citations. Figure 7 presents the results with a threshold of 50 citations and shows how journals are connected within the sustainable business models research area. Journal of Cleaner Production is unquestionably the leader among source titles, as it has been also proved in Table 6 by the largest number of citations received, and in Table 2, by the largest number of publications. Presented journals form three clusters, with Long Range Planning being the most important journal in the first, and the biggest cluster (marked in red); Journal of Cleaner Production being the most important in the second cluster (marked in green); and Harvard Business Review in the third (marked in blue).

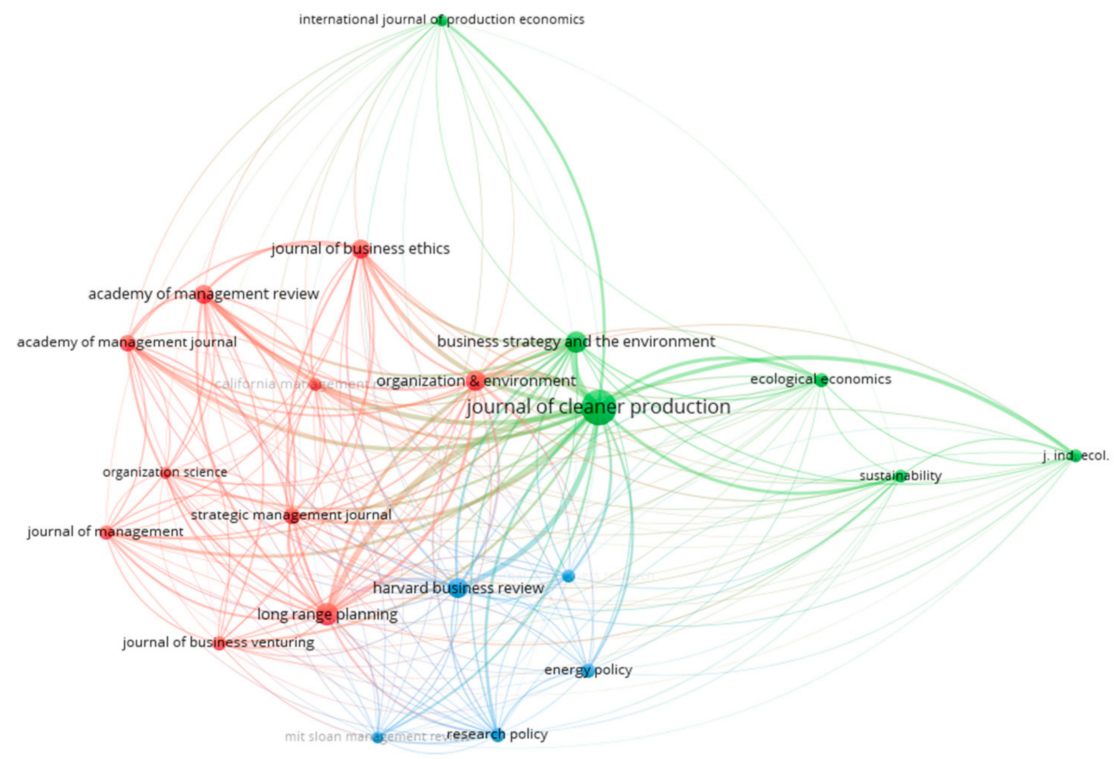

Figure 7. Co-citation of source titles cited in sustainable business models research area. Source: own elaboration based on the VOSviewer software.

Finally, the co-occurrence analysis of keywords on sustainable business models research is developed (Figure 8). This analysis allowed to identify the most popular topics in the field based on the analysis of 1005 keywords associated with all publications on sustainable business models classified as related to business and economics studies, where minimum number of occurrences of a keyword was set to 4 . Terms "sustainable business model" and "sustainable business models" are the most popular in the analyzed research stream and cumulatively occurred 97 times. This does not come as a surprise. Among the five most popular keywords, "sustainability" and "business model(s)" occurred as well. The knowledge base associated with sustainable business models in business and economics studies can be divided into six broad thematic clusters:

- Cluster 1 (red): related to corporate sustainability, 
- Cluster 2 (green): related to business models and entrepreneurship,

- Cluster 3 (blue): related to sustainable business models and circular economy,

- Cluster 4 (yellow): related to sustainability and entrepreneurship,

- Cluster 5 (purple): related to sustainable business models and value creation,

- Cluster 6 (light blue): related to innovation and sustainability.

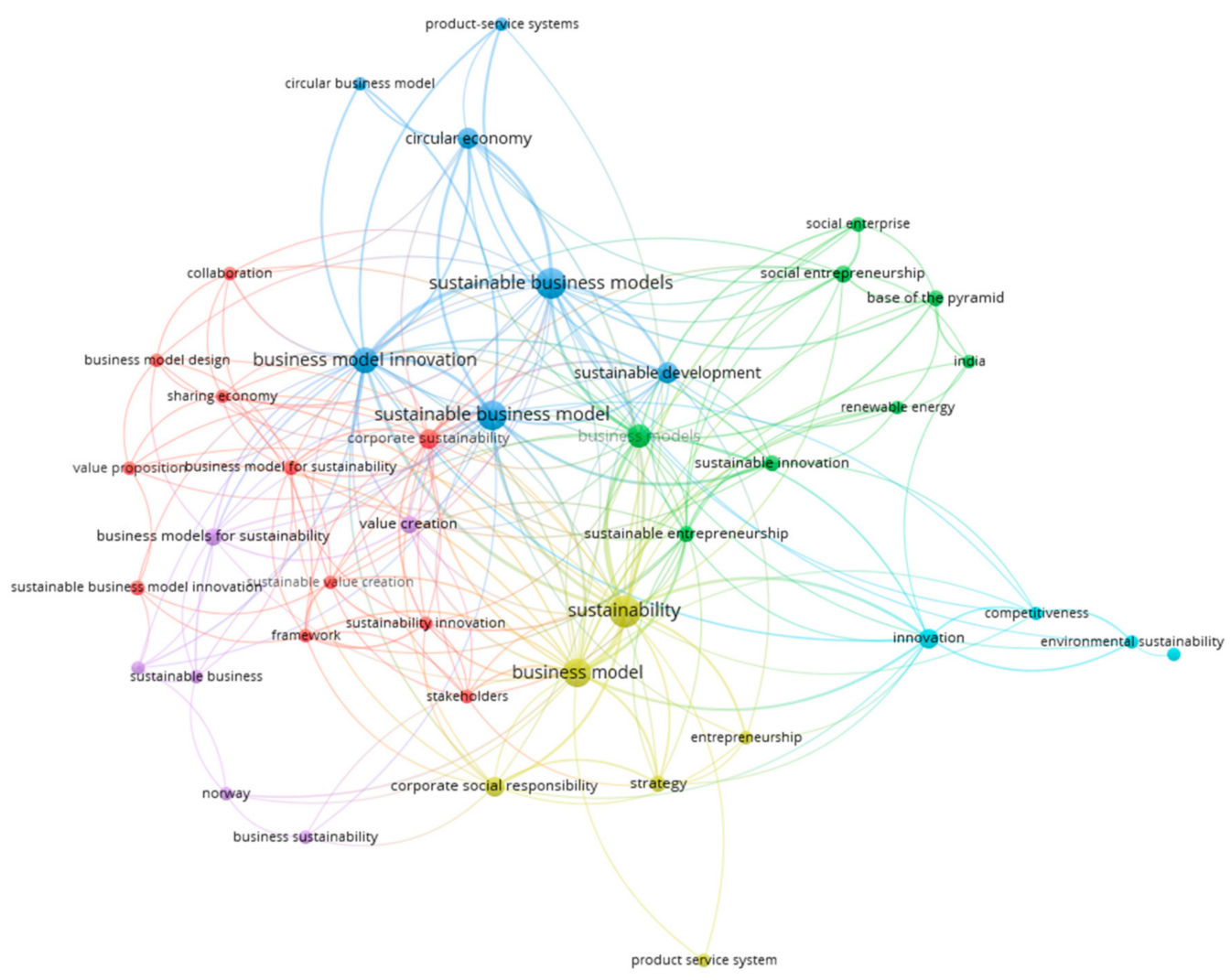

Figure 8. Co-occurrence of authors keywords of publications released in sustainable business models' research. Source: own elaboration based on the VOSviewer software.

The leading keywords represent novel approaches of companies to their business models, which adopt sustainable business models as leverage of their sustainable performance and increase their competitive advantage as it was mentioned in the introduction part after [1]. This novel approach and still ongoing rapid internationalization of companies have a central role in the analyzed research area, which makes a strong connection to the other keywords mentioned in Figure 8. Moreover, it represents the different theoretical frameworks that explain phenomena associated with this appealing area of research.

\section{Discussion and Conclusions}

The analysis presented above, based on performance bibliometric analysis and a graphic mapping of the research area, allowed the authors to answer three research questions presented in the Introduction, thereby (1) describing the most influential and high-impact researchers/authors, journals, and papers; (2) highlighting the main and most important research trends related to sustainable business models in studies on business and economics; and (3) identifying future research agendas in investigating sustainable business models from business and economics perspectives.

The results showed that sustainable business models research area has had a significant increase in recent years, especially in the last decade. The graphic mapping allowed to state that the research of sustainable business models' area is concentrated overwhelmingly in countries and institutions from 
Europe and North America continents with leading positions of researchers affiliated in institutions in United Kingdom, the Netherlands and Sweden, including University of Cambridge, Technische Universiteit Delft and Lunds Universitet. Countries of other continents not mentioned above appear more notable in recent years, however, they are still far from the highest productivity positions.

The authors summarized the answers to research questions and briefly described the obtained results below.

RQ1 concerned sources, scholars, and papers that have been most influential in research on sustainable business models overtime in studies related to business and economics.

The analyses allowed to conclude that nearly one third of analyzed papers were published in the Journal of Cleaner Production. It is also the most cited journal in the analyzed research area with 4232 total citations and most co-cited journals. Overall, it is ranked among 10 of the most influential journals in sustainable business models research and listed among top co-cited journals. Other influential journals looking at number of papers, citations and co-citations include Organization and Environment, as well as Business Strategy and the Environment. Looking at the overall influence of the journal without co-citations, the most influential ones are: International Journal of Innovation and Sustainable Development, Journal of Business Ethics, Corporate Governance (Bingley), Journal of Manufacturing Technology Management, Resources, Conservation and Recycling, International Journal of Retail \& Distribution Management, International Journal of Electronic Commerce, International Journal of Innovation Management.

Focusing on researchers, both bibliometric approaches allowed to identify the most influential authors, including: Bocken N.M.P. (affiliated in several institutions: e.g., University of Cambridge, Cambridge, UK as in [23,25]; Delft University of Technology, Delft, the Netherland, as in [22]; without limitation to these institutions alone), Lüdeke-Freund F. (affiliated in several institutions: e.g., Leuphana University Lüneburg, Lüneburg, Germany as in [9,27]; University of Hamburg, Hamburg, Germany as in [21]; without limitation to these institutions alone), Boons F. (affiliated in several institutions: e.g., University of Manchester, Manchester, United Kingdom, without limitation to this institutions alone), and Zott C. (affiliated in IESE Business School, Barcelona, Spain according to the Scopus database). Considering the number of publications and citations, the leading researchers are Bocken N.M.P. and Evans S.

The 10 most impactful papers in sustainable business models' research area are (listed in accordance with their rank): $[9,18,23,24,27,29,35,51,59,60]$ (Table 8). Interestingly, high-impact papers constituted a different ranking than highly cited papers. However, most of the latter ones were still contributions of high importance and are included in the ranking of the 20 most influential contributions in the different order.

Based on all bibliometric analyses presented in this paper, the additional conclusions can be proclaimed, e.g., the number of citations depends on: duration of the publication being exposed on research market, the recognition of (co-)authors of the publication, the circle of researchers gathered around the particular author, the thematic relationship of the research, the fashion for a given type of research, etc.

RQ2 allowed to uncover the main and most important research trends related to sustainable business models in business and economics studies.

The analysis of keywords associated with main contributions to the topic of sustainable business models and the most important journals publishing such research results allowed to highlight the main and most important research trends. Journal of Cleaner Production, which until 2020 publish almost one third of all papers on sustainable business models in business and economics studies focuses mainly on (1) circular economy and business models and (2) entrepreneurship and sustainability. Other important journals, i.e., Business Strategy and the Environment, as well as in Organization and Environment, prefer contributions related to organizational perspective, whereas British Food Journal is even more thematically focused and deals mainly with sustainability in food industry. High impact papers and papers published by the three most productive institutions share two common topics, namely (1) sustainable business models and value creation, (2) sustainable business models and circular 
economy and additionally concentrate on one more each: sustainable business models and corporate sustainability - the first one, sustainable business models, and innovation-the latter one. The analysis of all keywords associated with the publications on sustainable business models related to business and economics studies can be divided into six broad thematic clusters related to the following topics: (1) corporate sustainability, (2) business models and entrepreneurship, (3) sustainable business models and circular economy, (4) sustainability and entrepreneurship, (5) sustainable business models and value creation, (6) innovation and sustainability. To sum up the research results presented above, the main and most important research trends related to sustainable business models include entrepreneurship, sustainability, value creation, circular economy, and innovation.

RQ3 addressed future research directions in investigating sustainable business models from business and economics perspectives. Drawing on the research results presented above and identifying the most important research trends related to sustainable business models, future research directions in investigating sustainable business models from business and economics perspectives may include the following topics: evaluation of sustainable business models design and adoption in various sectors and countries; adoption of sustainable business models as a way to address challenges related do SDGs; sustainable business models and value co-creation; evaluation of the impact of sustainable business models adoption on circular economy performance; and service innovations resulting from adopting sustainable business models. Future research agendas listed above are derived from the outcomes of this research juxtaposed with selected contemporary research directions related to specific research trends identified in RQ2. Table 11 presents briefly described future research directions, including particular examples of research questions.

Table 11. Future research directions in investigating sustainable business models from business and economics perspectives.

\begin{tabular}{|c|c|c|}
\hline $\begin{array}{l}\text { Most Important Research Trends Related to } \\
\text { Sustainable Business Models in Business and } \\
\text { Economics Studies }\end{array}$ & Future Research Directions & Examples of Research Questions \\
\hline Entrepreneurship & $\begin{array}{l}\text { Evaluation of sustainable business } \\
\text { models design and adoption in } \\
\text { various sectors and countries. }\end{array}$ & $\begin{array}{l}\text { 1. To what extent sustainable business models are } \\
\text { sector and country specific? } \\
\text { 2. How do sustainable business models vary } \\
\text { across sectors and countries? }\end{array}$ \\
\hline Sustainability & $\begin{array}{l}\text { Adoption of sustainable business } \\
\text { models as a way to address } \\
\text { challenges related do SDGs. }\end{array}$ & $\begin{array}{l}\text { What are the required characteristics of } \\
\text { sustainable business models, which facilitate the } \\
\text { achievement of SDGs? }\end{array}$ \\
\hline Value creation & $\begin{array}{l}\text { Sustainable business models and } \\
\text { value co-creation. }\end{array}$ & $\begin{array}{l}\text { What are the mechanisms of value co-creation } \\
\text { that stimulate the transition from traditional } \\
\text { towards sustainable business models? }\end{array}$ \\
\hline Circular economy & $\begin{array}{l}\text { Evaluation of the impact of } \\
\text { sustainable business models } \\
\text { adoption on circular economy } \\
\text { performance. }\end{array}$ & $\begin{array}{l}\text { How does adoption of sustainable business } \\
\text { models stimulate circular economy } \\
\text { developments? }\end{array}$ \\
\hline Innovation & $\begin{array}{l}\text { Service innovations resulting from } \\
\text { adopting sustainable business } \\
\text { models }\end{array}$ & $\begin{array}{l}\text { How do sustainable business models compare to } \\
\text { traditional ones in terms of service innovation } \\
\text { development? }\end{array}$ \\
\hline
\end{tabular}

Source: own elaboration based on research results.

The future research directions given in Table 11 are direct effects of analysis presented in this article. Nevertheless, it is also worth considering other potential directions, which could not be foreordained before (the analysis covered only until the first quarter of 2020) and currently could also be derived from a highly important challenge of present times, namely COVID-19 pandemic. This seems to be of great importance for future research, and thus, surely will affect companies' performance and decisions, as well as policy objectives related to sustainability set by policy makers.

The current global situation will surely affect, among others, design and implementation of sustainable business models, thus, it is worth considering. Among interesting research topics, researchers may be willing to investigate disturbances of the concept of sustainable business models, which has arisen during the COVID-19 pandemic and will be the result of it (e.g., welfare of humanity vs. welfare of the environment vs. welfare of economy and business). Future research may, among others, 
concern comparison of specific case studies of sustainable business models before the pandemic, during attempts to suppress it and in the further long-time horizon, including after pandemic challenges' completion. It is expected that the concept of sustainable business models may be restructured and adapted to new challenges such as domestic lockdowns, and thus, it will be worth it to reconsider and redesign sustainable business models archetypes and search for contemporary business contributions to a sustainable development of the natural environment and society. All in all, challenges related to the COVID-19 pandemic may result in the need to reconceptualize current theories and frameworks related to sustainable business models, e.g., concerning drivers and barriers to business models for sustainability [66]. Recent studies on the relationship between sustainable business models and pandemics have already begun to emerge, for example $[67,68]$. In the current perspective of changes evoked by COVID-19 pandemic, it may become even more significant and worth further analyses.

The analysis presented in this paper may be useful for other researchers interested in exploring topics related to sustainable business models. Research results may serve as an inspiration for further conceptualization of their research agendas, finding collaborators among the most influential scholars in this research field, identifying matching institutions affiliating the most important scholars and papers, or selecting journals interested in publishing research results on sustainable business models.

Although the research allowed to present some interesting conclusions, there are research limitations that should be taken into account as well. Firstly, the presented analysis covers records available in the Scopus database, written in English, published as articles, conference papers, reviews, and conference reviews in the following Scopus subject areas: Business, Management and Accounting and Economics, Econometrics and Finance. It can be presumed that there are other highly influential and important publications that are not indexed in the chosen database. Secondly, the influence of analyzed contributions was researched, taking into account the number of records available in the Scopus database in a specific timeframe (2002-2020, with only the first quarter of 2020 analyzed). This should be considered while drawing general conclusions related to sustainable business models research area. Last, but not least, the results presented in this paper are meant to be informative, not evaluative, and authors did not intend to discredit any of the mentioned authors, publications or journals.

Author Contributions: Conceptualization, M.M. and M.K.; methodology, M.M. and M.K.; software, M.M. and M.K.; validation, M.M. and M.K.; formal analysis, M.M. and M.K.; investigation, M.M. and M.K.; resources, M.M. and M.K.; data curation, M.M. and M.K.; writing—original draft preparation, M.M. and M.K.; writing一review and editing, M.M. and M.K.; visualization M.M. and M.K.; funding acquisition, M.M. All authors have read and agreed to the published version of the manuscript.

Funding: The APC was partially funded by the Faculty of Management, University of Warsaw.

Conflicts of Interest: The authors declare no conflict of interest.

\section{References}

1. Porter, M.E.; Kramer, M.R. Creating shared value. Harv. Bus. Rev. 2011, 89, 62-77.

2. Shaltegger, S.; Lüdeke-Freund, F.; Hansen, E.G. Business Cases for Sustainability and the Role of Business Model Innovation: Developing a Conceptual Framework. 2011. Available online: http://www2.leuphana.de/umanagement/csm/content/nama/downloads/download_publikationen/ Schaltegger_Luedeke_Freund_Hansen_Business_Case_Sustainability.pdf (accessed on 9 March 2016).

3. Bradley, P.; Parry, G.; O'Regan, N. A framework to explore the functioning and sustainability of business models. Sustain. Prod. Consum. 2020, 21, 57-77. [CrossRef]

4. Kim, M. Strategies of Korean firms in China's high-tech market: Striving for a new and sustainable business model. Glob. Econ. Rev. 2004, 33, 61-75. [CrossRef]

5. Saeed, K.A.; Hwang, Y.; Grover, V. Investigating the impact of web site value and advertising on firm performance in electronic commerce. Int. J. Electron. Commer. 2002, 7, 119-141. [CrossRef]

6. Geissdoerfer, M.; Vladimirova, D.; Evans, S. Sustainable business model innovation: A review. J. Clean. Prod. 2018, 198, 401-416. [CrossRef] 
7. Jabłoński, M. Determinants of Sustainable Business Model of Companies Early Stage of Development. In Sustainable Business, Management, and Economics; Berger, L., Bergman, M.M., Eds.; Frontiers in Sustainability Series 1; MDPI: Basel, Switzerland, 2017; Volume 2, pp. 40-67. [CrossRef]

8. Upward, A.; Jones, P. An Ontology for Strongly Sustainable Business Models: Defining an Enterprise Framework Compatible with Natural and Social Science. Organ. Environ. 2016, 29, 97-123. [CrossRef]

9. Boons, F.; Lüdeke-Freund, F. Business models for sustainable innovation: State-of-the-art and steps towards a research agenda. J. Clean. Prod. 2013, 45, 9-19. [CrossRef]

10. Comin, L.C.; Aguiar, C.C.; Sehnem, S.; Yusliza, M.-Y.; Cazella, C.F.; Julkovski, D.J. Sustainable business models: A literature review. Benchmarking Int. J. 2019, 27, 2028-2047. [CrossRef]

11. Small-Warner, K.; Abuzeinab, A.; Taki, A. A Review of Sustainable Business Models and Strategic Sustainable Development. J. Bus. Models 2018, 6, 84-89.

12. Schaltegger, S.; Hansen, E.G.; Lüdeke-Freund, F. Business Models for Sustainability: Origins, Present Research, and Future Avenues. Organ. Environ. 2016, 29, 3-10. [CrossRef]

13. Abdelkafi, N.; Täuscher, K. Business models for sustainability from a system dynamics perspective. Organ. Environ. 2016, 29, 74-96. [CrossRef]

14. D'Amato, D.; Veijonaho, S.; Toppinen, A. Towards sustainability? Forest-based circular bioeconomy business models in Finnish SMEs. For. Policy Econ. 2020, 110, 101848. [CrossRef]

15. Maassen, M.A. Sustainable Business Models: An Imperative in the Strategic Management of Companies and Organizations. Manag. Dyn. Knowl. Econ. 2018, 6, 323-335. [CrossRef]

16. Jabłoński, A. Modele Zrównoważonego Biznesu w Budowie Długoterminowej Wartości Przedsiębiorstw z Uwzględnieniem ich Społecznej Odpowiedzialności; Difin: Warszawa, Poland, 2013; pp. 1-440.

17. Morioka, S.N.; Bolisa, I.; Evans, S.; Carvalho, M.M. Transforming sustainability challenges into competitive advantage: Multiple case studies kaleidoscope converging into sustainable business models. J. Clean. Prod. 2017, 167, 723-738. [CrossRef]

18. Evans, S.; Vladimirova, D.; Holgado, M.; Van Fossen, K.; Yang, M.; Silva, E.; Barlow, C. Business model innovation for sustainability: Towards a unified perspective for creation of sustainable business models. Bus. Strateg. Environ. 2017, 26, 597-608. [CrossRef]

19. Rauter, R.; Jonker, J.; Baumgartner, R.J. Going one's own way: Drivers in developing business models for sustainability. J. Clean. Prod. 2017, 140, 144-154. [CrossRef]

20. Peric, M.; Durkin, J.; Vitezic, V. The Constructs of a Business Model Redefined: A Half-Century Journey. Sage Open 2017, 1-13. [CrossRef]

21. Schaltegger, S.; Lüdeke-Freund, F.; Hansen, E.G. Business Models for Sustainability: A Co-Evolutionary Analysis of Sustainable Entrepreneurship. Innovation, and Transformation. Organ. Environ. 2016, 29, 264-289. [CrossRef]

22. Geissdoerfer, M.; Bocken, N.M.P.; Hultink, E.J. Design thinking to enhance the sustainable business modelling process-A workshop based on a value mapping process. J. Clean. Prod. 2016, 135, 1218-1232. [CrossRef]

23. Bocken, N.M.P.; Short, S.W.; Rana, P.; Evans, S. A literature and practice review to develop sustainable business model archetypes. J. Clean. Prod. 2014, 65, 42-56. [CrossRef]

24. Boons, F.; Montalvo, C.; Quist, J.; Wagner, M. Sustainable innovation, business models and economic performance: An overview. J. Clean. Prod. 2013, 45,1-8. [CrossRef]

25. Bocken, N.; Short, S.; Rana, P.; Evans, S. A value mapping tool for sustainable business modelling. Corp. Gov. 2013, 13, 482-497. [CrossRef]

26. Garetti, M.; Taisch, M. Sustainable manufacturing: Trends and research challenges. Prod. Plan. Control: Manag. Oper. 2012, 23, 83-104. [CrossRef]

27. Schaltegger, S.; Lüdeke-Freund, F.; Hansen, E.G. Business Cases for Sustainability: The Role of Business Model Innovation for Corporate Sustainability. Int. J. Innov. Sustain. Dev. 2012, 6, 95-119. [CrossRef]

28. Lüdeke-Freund, F. Towards a Conceptual Framework of 'Business Models for Sustainability. In Proceedings of the Knowledge Collaboration \& Learning for Sustainable Innovation: 14th European Roundtable on Sustainable Consumption and Production (ERSCP) Conference and the 6th Environmental Management for Sustainable Universities (EMSU) Conference (ERSCP-EMSU Conference 2010), Delfth, The Netherlands, 25-29 October 2010; Wever, R., Quist, J., Tukker, A., Woudstra, J., Boons, F., Beute, N., Eds.; Delft University of Technology: Delft, The Netherlands, 2010; pp. 1-28. Available online: https://ssrn.com/abstract=2189922 (accessed on 9 November 2020). 
29. Stubbs, W.; Cocklin, C. Conceptualizing a "Sustainability Business Model”. Organ. Environ. 2008, 21, $103-127$. [CrossRef]

30. Hajiheydari, N.; Talafidaryani, M.; Khabiri, S.; Salehi, M. Business model analytics: Technically review business model research domain. Foresight 2019, 21, 654-679. [CrossRef]

31. Wells, P. Sustainable business models and the automotive industry: A commentary. Iimb Manag. Rev. 2013, 25, 228-239. [CrossRef]

32. Secinaro, S.; Brescia, V.; Calandra, D.; Biancone, P. Employing bibliometric analysis to identify suitable business models for electric cars. J. Clean. Prod. 2020, 264, 1-15. [CrossRef]

33. Wit, B.; Pylak, K. Implementation of triple bottom line to a business model canvas in reverse logistics. Electron. Mark. 2020, in press. [CrossRef]

34. Nieuwenhuis, P. Alternative business models and entrepreneurship: The case of electric vehicles. Int. J. Entrep. Innov. 2018, 19, 33-45. [CrossRef]

35. Geissdoerfer, M.; Morioka, S.N.; De Carvalho, M.M.; Evans, S. Business models and supply chains for the circular economy. J. Clean. Prod. 2018, 190, 712-721. [CrossRef]

36. Di Tullio, P.; Valentinetti, D.; Rea, M.A. The competitiveness of firms through the sustainable business model: A decade of research. Industria 2018, 39, 357-386.

37. Nosratabadi, S.; Mosavi, A.; Shamshirband, S.; Zavadskas, K.E.; Rakotonirainy, A.; Chau, K.W. Sustainable Business Models: A Review. Sustainability 2019, 11, 1663-1693. [CrossRef]

38. GRI, UN Global Compact, WBCSD. SDG Compass. The Guide for Business Action on the SDGs. Available online: https://sdgcompass:wp-content/uploads/2015/12/019104_SDG_Compass_Guide_2015.pdf (accessed on 6 June 2020).

39. Alvino, F.; Di Vaio, A.; Hassan, R.; Palladino, R. Intellectual capital and sustainable development: A systematic literature review. J. Intellect. Cap. 2020, in press. [CrossRef]

40. Grant, M.J.; Booth, A. A typology of reviews: An analysis of 14 review types and associated methodologies. Health Info. Libr. J. 2009, 26, 91-108. [CrossRef] [PubMed]

41. Petticrew, M.; Roberts, H. Systematic Reviews in the Social Sciences: A Practical Guide; Blackwell: Oxford, UK, 2006. [CrossRef]

42. Baier-Fuentes, H.; Merigó, J.M.; Amorós, J.E.; Gaviria-Marín, M. International entrepreneurship: A bibliometric overview. Int. Entrep. Manag. J. 2019, 15, 385-429. [CrossRef]

43. Scopus Database's Content Introduction. Available online: https://www.elsevier.com/solutions/scopus/howscopus-works/content (accessed on 6 May 2020).

44. Scopus Database. Available online: https://www.elsevier.com/solutions/scopus/how-scopus-works/content/ content-policy-and-selection (accessed on 6 May 2020).

45. Mongeon, P.; Paul-Hus, A. The journal coverage of web of science and Scopus: A comparative analysis. Scientometrics 2016, 106, 213-228. [CrossRef]

46. Clarivate Web of Science. Why Choose the Web of Science Core Collection? 2020. Available online: https://clarivate.com/webofsciencegroup/solutions/web-of-science-core-collection/ (accessed on 6 May 2020).

47. Sustainable Development Goals (2030 Agenda). Available online: https://ec.europa.eu/environment/ sustainable-development/SDGs/index_en.htm (accessed on 25 September 2020).

48. Sachs, J.; Schmidt-Traub, G.; Kroll, C.; Lafortune, G.; Fuller, G. Sustainable Development Report 2019; Bertelsmann Stiftung and Sustainable Development Solutions Network (SDSN): New York, NY, USA, 2019; Available online: https://dashboards.sdgindex:\#/ (accessed on 4 May 2020).

49. Tredoux, C.T.; Durheim, K. Numbers, Hypotheses and Conclusions: A Course in Statistics for the Social Sciences; UCT Press: Cape Town, South Africa, 2002.

50. Van Aswegen, A.S.; Engelbrecht, A.S. The relationship between transformational leadership, integrity and an ethical climate in organisations. S. Afr. J. Hum. Resour. Manag. 2009, 7, 221-229. [CrossRef]

51. Murray, A.; Skene, K.; Haynes, K. The Circular Economy: An Interdisciplinary Exploration of the Concept and Application in a Global Context. J. Bus. Ethics 2017, 140, 369-380. [CrossRef]

52. Merigó, J.M.; Gil-Lafuente, A.M.; Yager, R.R. An overview of fuzzy research with bibliometric indicators. Appl. Soft Comput. 2015, 27, 420-433. [CrossRef]

53. Merigó, J.M.; Mas-Tur, A.; Roig-Tierno, N.; Ribeiro-Soriano, D. A bibliometric overview of the journal of business research between 1973 and 2014. J. Bus. Res. 2015, 68, 2645-2653. [CrossRef] 
54. Beatty, S. Journal Metrics in Scopus: Source Normalized Impact per Paper (SNIP). 2016. Available online: https://blog.scopus.com/posts/journal-metrics-in-scopus-source-normalized-impact-per-paper-snip (accessed on 10 May 2020).

55. Beatty, S. Journal Metrics in Scopus: SCImago Journal Rank (SJR). 2016. Available online: https://blog.scopus. com/posts/journal-metrics-in-scopus-scimago-journal-rank-sjr (accessed on 10 May 2020).

56. Raj, R.G.; Zainab, A.N. Relative measure index: A metric to measure the quality of journals. Scientometrics 2012, 93, 305-317. [CrossRef]

57. Høgevold, N.M. A corporate effort towards a sustainable business model: A case study from the Norwegian furniture industry. Eur. Bus. Rev. 2011, 23, 392-400. [CrossRef]

58. Tseng, M.-L.; Chiu, A.S.F.; Tan, R.R.; Siriban-Manalang, A.B. Sustainable consumption and production for Asia: Sustainability through green design and practice. J. Clean. Prod. 2013, 40,1-5. [CrossRef]

59. Witjes, S.; Lozano, R. Towards a more Circular Economy: Proposing a framework linking sustainable public procurement and sustainable business models. Resour. Conserv. Recycl. 2016, 112, 37-44. [CrossRef]

60. Joyce, A.; Paquin, R.L. The triple layered business model canvas: A tool to design more sustainable business models. J. Clean. Prod. 2016, 135, 1474-1486. [CrossRef]

61. Matos, S.; Silvestre, B.S. Managing stakeholder relations when developing sustainable business models: The case of the Brazilian energy sector. J. Clean. Prod. 2013, 45, 61-73. [CrossRef]

62. Scheepens, A.E.; Vogtländer, J.G.; Brezet, J.C. Two life cycle assessment (LCA) based methods to analyse and design complex (regional) circular economy systems. Case: Making water tourism more sustainable. J. Clean. Prod. 2016, 114, 257-268. [CrossRef]

63. Yang, M.; Evans, S.; Vladimirova, D.; Rana, P. Value uncaptured perspective for sustainable business model innovation. J. Clean. Prod. 2017, 140, 1794-1804. [CrossRef]

64. França, C.L.; Broman, G.; Robèrt, K.-H.; Basile, G.; Trygg, L. An approach to business model innovation and design for strategic sustainable development. J. Clean. Prod. 2017, 140, 155-166. [CrossRef]

65. Van Eck, N.J.; Waltman, L. Software survey: VOSviewer, a computer program for bibliometric mapping. Scientometrics 2010, 84, 523-538. [CrossRef] [PubMed]

66. Lüdeke-Freund, F. Sustainable entrepreneurship, innovation, and business models: Integrative framework and propositions for future research. Bus. Strateg. Environ. 2020, 29, 665-681. [CrossRef]

67. Hamilton, J. The Strategic Change Matrix and Business Sustainability across COVID-19. Sustainability 2020, 12, 6026. [CrossRef]

68. Cavicchi, C.; Vagnoni, E. Sustainable Business Models in Hybrids: A Conceptual Framework for Community Pharmacies' Business Owners. Sustainability 2020, 12, 8125. [CrossRef]

Publisher's Note: MDPI stays neutral with regard to jurisdictional claims in published maps and institutional affiliations.

(C) 2020 by the authors. Licensee MDPI, Basel, Switzerland. This article is an open access article distributed under the terms and conditions of the Creative Commons Attribution (CC BY) license (http://creativecommons.org/licenses/by/4.0/). 